\begin{tabular}{|c|c|c|c|}
\hline Article Info & ARAŞTIRM & RESEARCH MAKALESİ & \\
\hline Title of Article & \multicolumn{2}{|c|}{$\begin{array}{c}\text { The Gates of Izmir: Migration Stories and } \\
\text { Living Conditions of Urban Refugees }\end{array}$} & \\
\hline $\begin{array}{l}\text { Corresponding } \\
\text { Author }\end{array}$ & \multicolumn{2}{|c|}{$\begin{array}{l}\text { Emel KARAKAYA AYALP } \\
\text { Assistant Professor Dr., İzmir Democracy University, Faculty of Architecture, Department } \\
\text { of City and Regional Planning, emellkarakaya@gmail.com }\end{array}$} & \\
\hline $\begin{array}{l}\text { Received Date } \\
\text { Accepted Date }\end{array}$ & \multicolumn{2}{|c|}{$\begin{array}{ll}14.08 .2021 \\
13.09 .2021\end{array}$} & \\
\hline Doi Number & \multicolumn{2}{|c|}{ https://doi.org/10.35674/kent.982721 } & \\
\hline Author / Authors & $\begin{array}{l}\text { Emel KARAKAYA AYALP } \\
\text { Esen YANGIN KİREMIT }\end{array}$ & $\begin{array}{l}\text { ORCID: 0000-0001-9469-9657 } \\
\text { ORCID: 0000-0002-5478-9647 }\end{array}$ & \\
\hline How to Cite & \multicolumn{2}{|c|}{$\begin{array}{l}\text { Karakaya Ayalp, E. and Yangın Kiremit, E. (2021). İzmir’in Kapıları: Kent } \\
\text { Mültecilerinin Göç Hikayeleri ve Yaşam Koşulları, Kent Akademisi, Volume, 14, Issue } \\
\text { 3, Pages, 659-686 }\end{array}$} & $\begin{array}{l}\text { Kent Akademisi } \\
\text { Urban Academy }\end{array}$ \\
\hline
\end{tabular}

\title{
İzmir'in Kapıları: Kent Mültecilerinin Göç Hikayeleri ve Yaşam Koşulları ${ }^{123}$ | The Gates of İzmir: Migration Stories and Living Conditions of Urban Refugees
}

Emel KARAKAYA AYALP Esen YANGIN KIREMIT ${ }^{5}$

\section{ÖZ:}

Bu çalışmada, İzmir'in Kapılar semtinde ikamet etmekte olan Suriyeli kent mültecileriyle yapılan görüşmelere ve bu görüşmelerde aktarılan göç hikâyelerine dayanarak; mevcut yerleşim alanındaki sosyal ve ekonomik koşulların ortaya koyulması amaçlanmıştır. Bu amaçlar doğrultusunda seçilen çalışma alanındaki 10 mahallede ikamet etmekte olan; farklı etnik köken, yaş ve gelir gruplarından, toplam 60 Suriyeli kent mültecisi ile derinlemesine görüşmeler gerçekleştirilmiştir. Görüşmelerde katılımcıların göç süreçleri, göç yolları, varış noktalarındaki ekonomik faaliyetleri, geçim kaynakları, kentle ve sosyal çevreyle kurudukları ilişkiler araştırılmıştır. İlgili yazında da İzmir'in bir geçiş kenti niteliği taşıdığı aktarılmaktadır. Ancak, araştırma sonuçlarından elde edilen bilgiler, bir geçiş kenti olmanın yanı sıra İzmir'in hedef kent olarak da seçildiğini ve yerleşmek üzere tercih edildiğini göstermektedir. Öte yandan, göç sürecinin iki uçlu bir hatta seyretmediği, bunun aksine devam eden, aktif bir süreçten bahsetmenin mümkün olduğu ifade edilebilir. Yaşam koşulları analizi göstermektedir ki, "geçici koruma" kapsamında iş piyasasına erişimde

1 Bu çalışma, TÜBİTAK 1003 Öncelikli Alanlar ve AR-GE programı kapsamında desteklenmekte olan "Kentsel Mültecilerin Adaptasyon ve Uyum Süreçlerine Yeni bir Bakış Açısı: Kapsayıcı Kent İnşası Amaçlı Sosyal İnovasyon Deneyi” başlıklı 117K826 (ana proje), 117K805ve $117 \mathrm{~K} 829$ kodlu projeler kapsamında gerçekleştirilmiştir.

2 Bu çalışmaya ilişkin etik kurul izin talebi "Yıldız Teknik Üniversitesi Akademik Etik Kurulu” tarafindan 24.05.2017 tarihinde, 55779672604.01.02-E.1705240179 sayılı belge ile onaylanmıştır.

3 Bu çalışma, 22-24 Șubat 2021 tarihlerinde Dokuz Eylül Üniversitesi tarafindan düzenlenen "Göç: Önümüzdeki Yirmi Yılın Projeksiyonu ve Ötesi” konulu Uluslararası konferansta sunulan, özet metin olarak basılmış olan aynı başlıklı bildirinin geliştirilmiş ve gözden geçirilmiş halidir.

4 Assistant Professor Dr., İzmir Democracy University, Faculty of Architecture, Department of City and Regional Planning, emellkarakaya@gmail.com

${ }^{5}$ Ph.D. Candidate, Dokuz Eylül University, Institute of Social Sciences, Department of Psychology, yangin.esen@ gmail.com 
yaşanan sorunlar, barınma dâhil kentsel hizmetlere erişimde yaşanan sorunlar ve toplumsal dişlanma gibi etmenler birlikte yaşam pratiğinin kurulmasında önemli engeller üretmektedir.

ANAHTAR KELIMELER: Kentsel Mülteciler, İzmir, Kent Mültecilerinin Yerleşim Tercihleri, Kent Mültecilerinin Kamusal Hizmetlere Erişimi, Göç Hikâyeleri

\begin{abstract}
:
In this study, we aim to reveal the social and economic conditions in the existing settlement by depending on the migration stories expressed in the interviews with Syrian urban refugees who resided in İzmir Kap1lar [Gates] district. For this purpose, 60 Syrian urban refugees from different ethnicity, age, and income groups who resided in 10 neighborhoods in the selected study area were interviewed. Their migration processes, migration routes, economic activities in destinations, sources of income and relations with the city and social environment were investigated in the interviews. The relevant literature states that İzmir has functioned as a transit city during mass migration due to the Syrian war. However, the results of this research show that İzmir was also chosen as a target city and preferred for permanent settling in addition to being a transit city. Besides, the migration process does not follow a two-pronged line, contrarily, it is more like an ongoing and active process. The analysis of living conditions shows that factors such as problems with accessing the labor market within the scope of "temporary protection"; problems with accessing urban services including housing, and problems with social exclusion create important obstacles in constructing a practice of living together.
\end{abstract}

KEYWORDS: Urban Refugees, İzmir, Settling Preferences of Urban Refugees, Urban Refugees’ Access to Public Services, Migration Stories

\title{
“İzmir’in Kapıları: Kent Mültecilerinin Göç Hikâyeleri ve Yaşam Koşulları”
}

\section{GíRiş}

Yirmi iki milyondan fazla mülteci son on yılda gelişmekte olan ülkelerde emek piyasasında kendine yer bulmaya çalışmaktadır. Bu nüfus dünya üzerindeki toplam mülteci nüfusunun \%85'ini oluşturmaktadır ve Suriye iç savaşı sonrasında dünyanın dört bir yanına dağılan Suriyeli mültecilerin kitlesel göçü sonrasında Türkiye dünyadaki en kalabalık Suriyeli nüfusa ev sahipliği yapan ülke haline gelmiştir (UNHCR, 2017).

UNHCR- United Nations High Commissionaire of Refugees (Birleşmiş Milletler Mülteciler Yüksek Komiserliği). (2017). Syria Regional Refugee Response. Operational Portal Refugee Situations. https://data2.unhcr.org/en/situations/syria (Erişim Tarihi: 10.01.2021)

Türkiye toplumuna eklenen bu yeni grup politik, sosyal, ekonomik, hukuksal pek çok yapının harekete geçmesini gerektirmiştir. Giderek Türkiye'nin kalıcı bir sosyal parçası haline gelen bu nüfusun, sosyal uyum ve adaptasyon süreçlerinin sağlıklı ve kontrollü yönetimi zorunluluk arz etmektedir. 
Şekil 1 İltica Edilen Ülkeye Göre Toplam Mülteci Sayısı

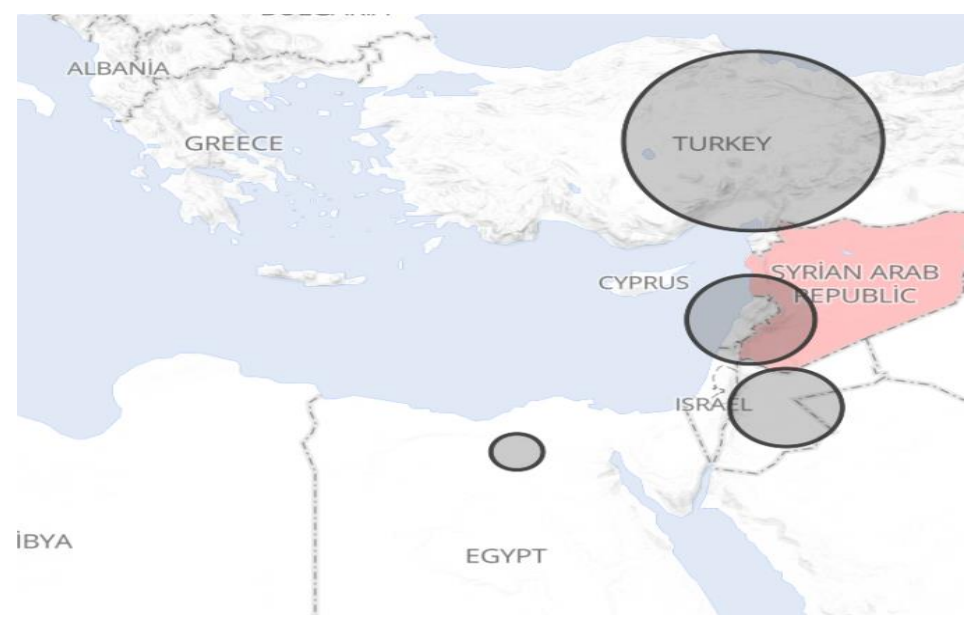

Günümüzde göçün yönü belirgin bir şekilde kentseldir ve kentlerin göç konusundaki önemi geçici bir mesele değildir (IOM, 2017, s. 33). Huang ve Graham'a göre (2018, s. 6), mülteciler açısından kentsel/metropoliten alanların iş piyasası ve emek piyasasına erişimde sunduğu olanaklar göçü bu alanlara yönlendirmektedir. İzmir, 2012 yılından itibaren göçmenler için Türkiye'de deniz yolu ile Avrupa'ya geçişlerin ve insan kaçakçılığının en yoğun olduğu kent olmuş ancak Türkiye'nin değişen rolü ile ev sahibi kente dönüşmüştür (Çamur, 2017, s.116; Şimşek, 2019, s. 504). Kentin tarım, sanayi ve hizmet sektörlerinde sunduğu istihdam olanaklarının yanı sıra, Avrupa'ya açılan kapılardan biri olmak özelliğiyle de Suriyeli göçmenler için çekim merkezi olduğu vurgulanmaktadır (Yıldız ve Uzgören, 2016, s. 2). Göç İdaresi Genel Müdürlüğü verilerine göre; İzmir, Suriyeli nüfusun yerleştiği şehirler sıralamasında sekizincidir. Güncel rakamlara bakıldığında, yaklaşık 150.000 "geçici koruma kapsamındaki" Suriyeli kent mültecisine ev sahipliği yapmaktadır. Konak, İzmir'de Suriyeli nüfusun en fazla yerleştiği ilçe olma özelliğini taşımaktadır (İzmir Valiliğ̣i İl Göç İdaresi Müdürlüğü, 2018).

Bu çalışmada, İzmir Kapılar semtinde ikamet etmekte olan Suriyeli kent mültecileri ile yapılan görüşmelere ve bu görüşmelerde aktarılan göç hikâyelerine dayanarak; mevcut yerleşim alanındaki sosyal ve ekonomik yaşam koşullarının ortaya koyulması amaçlanmıştır. Suriyelilerin göç süreçleri, varış noktalarındaki ekonomik faaliyetleri, kentle ve sosyal çevreyle kurudukları ilişkiler araştırılmıştır. Araştırma kapsamında ele aldığımız göç hikâyelerinde, göçmenlerin göçün başlangıç noktasından itibaren izlemiş oldukları yollar incelenmiş, aktif bir süreç olan göçün dünü, bugünü ve yarını incelenmiştir. Göçmenlerin mevcut yerleşim alanlarındaki yaşam koşulları iş gücü piyasasıyla kurulan ilişkiler, barınma koşulları, kamusal ve kentsel hizmetlere erişim, mahalle ölçeğinde Türkiyelilerle kurulan ilişiklerin niteliği kent içi hareketlilik çerçevesinde analiz edilmiştir. Son olarak göçün psikolojik çıktıları duygular, kaygılar ve gelecek beklentileri ölçeğinde ele almıştır.

\section{Yöntem}

\section{1. Çalışma Alanı ve Örneklem}

Çalışma kapsamında seçilen alan İzmir Basmane semtinde Kapılar ve çevresindeki 10 mahalleden oluşmaktadır. Kapılar, isminden de anlaşılacağı üzere kentin antik dönem giriş kapılarının bulunduğu alandır. Bu yönüyle, tarih boyunca kente yeni gelenlerin, göçmenlerin, mültecilerin vs. kente ilk giriş noktası olmuştur. Günümüzde de kente göçle gelen nüfusun ilk yerleşim noktalarından olduğu gibi Suriye krizinden önce Yunanistan'a geçiş amacı ile İzmir'e ulaşan Afrikalı ve Orta Doğulu nüfusun barındığı oteller bölgesi yine bu alandadır. Seçilen on mahalle, alanda mülteci nüfusun en yoğun olduğu mahallelerdir ve sınırları Kadifekale, Anafartalar caddesi ve Patlıcan yokuşu ile 
sınırlanmıştır. İzmir'in Konak ilçesinden seçilen on mahallede ikamet etmekte olan altmış Suriyeli kent mültecisiyle yarı yapılandırılmış ve yüz yüze derinlemesine görüşmeler ${ }^{6}$ yapılmıştır. Görüşmeciler 18 yaşını doldurmuş ve reşit bireylerden oluşmaktadır ve örneklem seçimi katılımcı olmaya gönüllülük esasına dayanmaktadır. Çalışmanın etik kurul izin talebi "Yıldız Teknik Üniversitesi Akademik Etik Kurulu" tarafından 24.05.2017 tarihinde, 55779672604.01.02-E.1705240179 sayılı belge ile onaylanmıştır. Görüşmeler Ekim 2018'de başlayıp Aralık 2018'de tamamlanmıştır. Mülakatların mahallelerdeki dağılımı mülteci nüfusunun mahalle nüfusuna oranı gözetilerek belirlenmiştir. Çalışmanın yürütüldüğü mahalleler, her bir mahalleden katılımcı sayısı, mahalle toplam ve mülteci nüfusuna ilişkin veriler Şekil 2'de ve Tablo 1'de gösterildiği gibidir.

Şekil 2 Araştırma Kapsamında İzmir Basmane Semtinde Çalışma Yapılan 10 Mahalle ve Mahallelerde Mülakat Noktaları

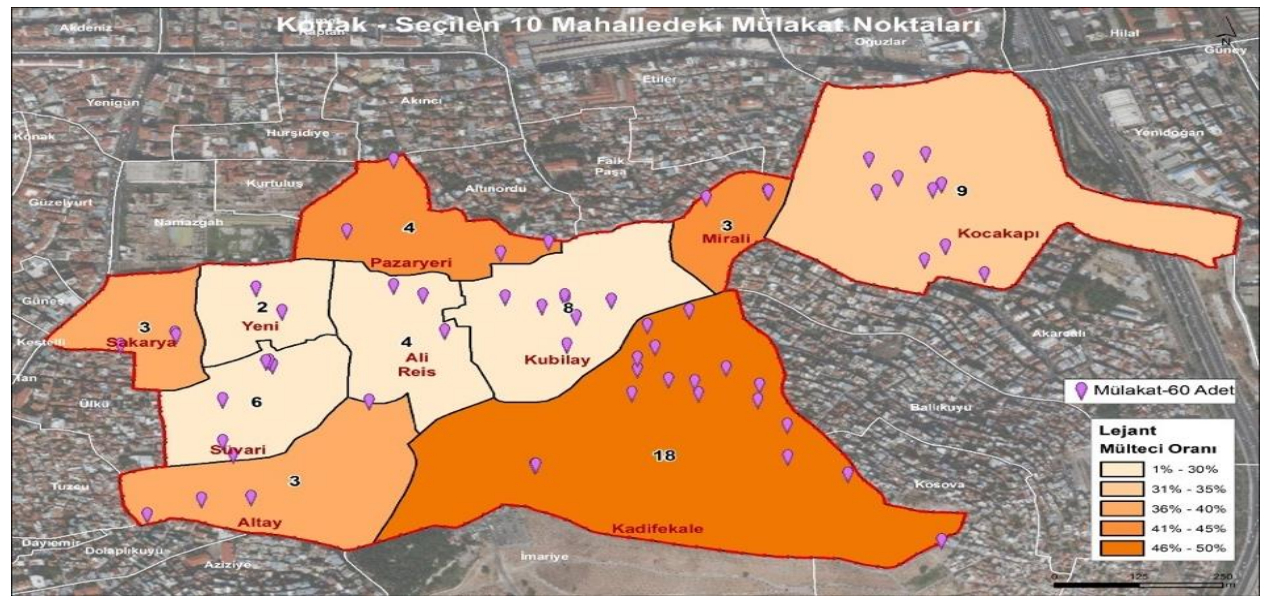

${ }^{6} \mathrm{Bu}$ makale kapsamında hazırlanan grafikler, tablolar ve şekiller 117K805 kodlu proje ekibi tarafından hazırlanmıştır. Tüm proje ekibine teşekkür ederiz. 
Tablo 1 Araştırma Kapsamında İzmir Basmane Semtinde Çalışma Yapılan 10 mahallenin Nüfusu, Mülteci Nüfusu ve Mülakat Sayısı

\begin{tabular}{|lllll|}
\hline Mahalle & Mahallenin Toplam Nüfusu & Mülteci Nüfusu (Eylül 2018) & Mülakat Sayısı \\
\hline 1 & Ali Reis & 2.000 & 528 & 6 \\
\hline 2 & Altay & 1.250 & 319 & 3 \\
\hline 3 & Kadifekale & 6.281 & 2.041 & 18 \\
\hline 4 & Kocakapi & 4.000 & 928 & 8 \\
\hline 5 & Kubilay & 4.000 & 768 & 7 \\
\hline 6 & Mirali & 1.201 & 379 & 3 \\
\hline 7 & Pazaryeri & 3.500 & 527 & 3 \\
\hline 8 & Sakarya & 2.000 & 359 & 5 \\
\hline 9 & Süvari & 2.700 & 589 & 2 \\
\hline 10 & Yeni & 1.500 & 274 & $\mathbf{6 0}$ \\
\hline & Toplam & $\mathbf{2 8 . 4 3 2}$ & $\mathbf{6 . 8 1 2}$ & 5 \\
\hline
\end{tabular}

Gerçekleştirilen altmış derinlemesine görüşme ortalama 90 dakika sürmüş; en kısa görüşme 40 dakika, en uzun görüşme 3 saat olarak kaydedilmiştir. Mülakatlarda, katılımcılar çalışmanın amacı ve kapsamı hakkında bilgilendirilmiş, kimlik bilgilerinin gizliliğinin korunacağı ifade edilmiş ve gönüllü onamları alınmıştır. Onay veren katılımcıların görüşmeleri ses kayıt cihazıyla kaydedilmiş, bunun yanı sıra görüşme esnasında araştırmacılar tarafından not tutulmuştur. Görüşmeler, bahsi geçen bilimsel araştırma projesi kapsamında yazarların da içinde bulunduğu araştırma ekibi tarafından gerçekleştirilmiş ve simültane çeviri ${ }^{7}$ yapılmıştır.

Bahsi geçen bilimsel araştırma projesi kapsamında gerçekleştirilen derinlemesine görüşmeler ile nitel bir veri seti elde edilmiştir. Ancak bu çalışma kapsamında bu nitel veri seti grafiksel veriye dönüştürülerek sunulmuştur. İlgili yazında, Türkiye'de Suriyeli kent mültecilerine ilişkin demografik özellikleri içeren nitel derinlemesine görüşmelere dayalı çalışmaların yer almadığı aktarılmaktadır (Makovsky, 2019). Türkiye'de 2015 yılından bu yana Suriyeli mülteciler üzerine yapılan çalışmaların sayısında çok hızlı bir artış olsa da yapılan çalışmalarda (Suriyeli) bireylerle gerçekleştirilen yüz yüze derinlemesine görüşmeler sinırlı olduğu gibi örneklem büyüklüğü de kısıtll1ıklar içerebilmektedir (bakınız Çelik ve İçduygu, 2018; Köser- Akçapar ve Şimsek; Şafak-Ayvazoğlu ve Kunuroğlu, 2021; Şafak- Ayvazoğlu, Kunuroğlu ve Yağmur, 2021; Yıldız ve Uzgören, 2016). Ayrıca, bu çalışma kapsamında sunulduğu üzere Suriyeli mültecilerin yoğun olarak yaşadığı, mekânsal olarak tanımlı bir alanda (bakınız Şekil 2) yoğun araştırmaya dayalı çalışmalar da yazında sıkça görülmemektedir. Bunların yanında, yüz yüze derinlemesine görüşmeler içeren araştırmaların bir kısmı STK'lar, kamu kurumlarında görev yapan bürokratlar, yerel yönetim yetkilileri gibi Suriyeli mülteciler dışındaki aktörlerle gerçekleştirilmiştir. Bu kapsamda, bu makale demografik özelliklerin, profilin ve göç sürecine dönük temel bulguların sunulmasını önceliklendirilerek veri analizini bu çerçevede gerçekleştirmiştir. Makalenin veri setinin üretildiği araştırma projesi de Türkiye'de yeni ortaya çıkmış olan bir olguyu araştırmak üzere tasarlanmış olan keşfedici bir araştırmadır. 60 derinlemesine görüşmeden elde edilen veri setinin çok büyük olması ve Türkiye'de kent mültecilerinin profilini tanımlayan çalışma sayısının sınırlı olması

${ }^{7}$ Simültane çeviriler bu makalenin yazarlarından Esen YANGIN KİREMITT tarafindan gerçekleştirilmiştir. 
nedenleriyle makalenin bu boşluğu doldurması hedeflenmiş ve ilgili veri setinin içinden seçilen bölümler grafiksel veriye dönüştürülerek sunulmuştur.

\subsection{Katılımcıların Demografik Özellikleri}

Örneklemin \%67'si (40 katılımcı) kadın, \%33’ü (20 katılımc1) erkeklerden oluşmaktadır. Katılımcıların 18-39 yaş aralığında yoğunlaşması itibariyle genç bir profil sergilediği görülmektedir. Eğitim durumu genellikle ilkokul ve ortaokul seviyesindedir. Katılımcıların anadili sorulduğunda Arapçanın ilk, Kürtçenin ikinci ve Türkçenin üçüncü sırada olduğu görülmüşsür. Katılımcıların çoğunluğu Suriye'den 2013 ve 2014 yıllarında göç etmiştir. Veri toplama işleminin gerçekleştirildiği tarih (2018) göz önünde bulundurulduğunda görüşmelerin gerçekleştirildiği sırada katılımcıların büyük bir kısmının 4-5 yıldır Türkiye'de bulunduğu söylenebilir.

\section{BULGULAR}

\subsection{Aktif Bir Süreç Olarak Göç}

Suriye'den İzmir'e uzanan göç yolculuğunda katılımcıların uğradıkları duraklar ve göç yolu analiz edildiğinde göçün iki uçlu tek bir hatta seyretmediği, İzmir'e varış ve yerleşme öncesi pek çok duraktan geçildiği anlaşılmaktadır. Katılımcıların göç süreci anlatılarında tespit edilen duraklardan hareketle oluşturduğumuz haritada da (Şekil 3) görüldüğü üzere Suriye sınırları dâhilinde yoğun bir hareketlilik göze çarpmaktadır. Katılımcılar, savaş sürecinde Türkiye'ye giriş yapmadan önce yaşadıkları şehirlerden başka şehirlere, aynı şehir içerisinde başka bölgelere ya da kırsal alandaki yerleşim alanlarına göç ederek Suriye içinde güvenli bölge arayışına gittiklerini ifade etmişlerdir. Savaşın giderek bütün bölgelere ve şehirlere yayılmasıyla birlikte Suriye içinde bütün çarelerin tükendiği ve son olarak Türkiye’ye giriş yapıldığı anlaşılmaktadır. Benzer şekilde Türkiye’ye giriş yapıldıktan sonra da ilk ya da tek durağın İzmir olmadığı, farklı kentlerin de katılımcılar tarafından çeşitli nedenlerle ziyaret edildiği anlaşılmaktadır. Bu kentlerden başlıcaları; yaya olarak ya da araç yolu ile erişilebilir olan sınır kapıları ve bu sınır kapılarının sınırları içerisindeki Hatay ve Kilis gibi kentlerdir. Göç geçiş mekânlarını gösteren Şekil 3 incelendiğinde, en yoğun hareket ve geçiş güzergâhının Türkiye'nin güney-güneydoğu sınırındaki kentlerden İzmir'e yöneldiği görülmektedir. Diğer bir yoğunlaşma, yine Türkiye'nin güney-güneydoğu sınır kentlerinden Türkiye'nin kuzeyindeki İstanbul gibi metropollere yönelen ve bu metropol kentlerden İzmir'e ulaşan bir hareket olarak görülmektedir. Benzer biçimde, görüşmecilerin İzmir'e gelmeden önce yaşadıkları iller incelendiğinde (Şekil 4), güney ve güneydoğu illeri ile İç Ege bölgesi öne çıkmaktadır. Göç geçiş mekânları haritası ile İzmir'e yerleşmeden önce yaşanılan iller haritası karşılaştırıldığında bazı illere (Ankara, Kayseri, Bilecik gibi) sadece geçiş mekânı olarak uğrandığı anlaşılmaktadır. $\mathrm{Bu}$ durumun bir nedenin de kent mültecilerinin ülke içinde seyahat ederken yaşadıkları çeşitli güçlükler olduğu anlaşılmaktadır. Bazı kentlerde kayıt yaptırmak konusunda yaşanan sorunlar, konut ve istihdam sorunları diğer başlıca nedenlerdir. 
Şekil 1 İzmir'de Sonlanan Göç Güzergâhları ve Geçiş Noktaları

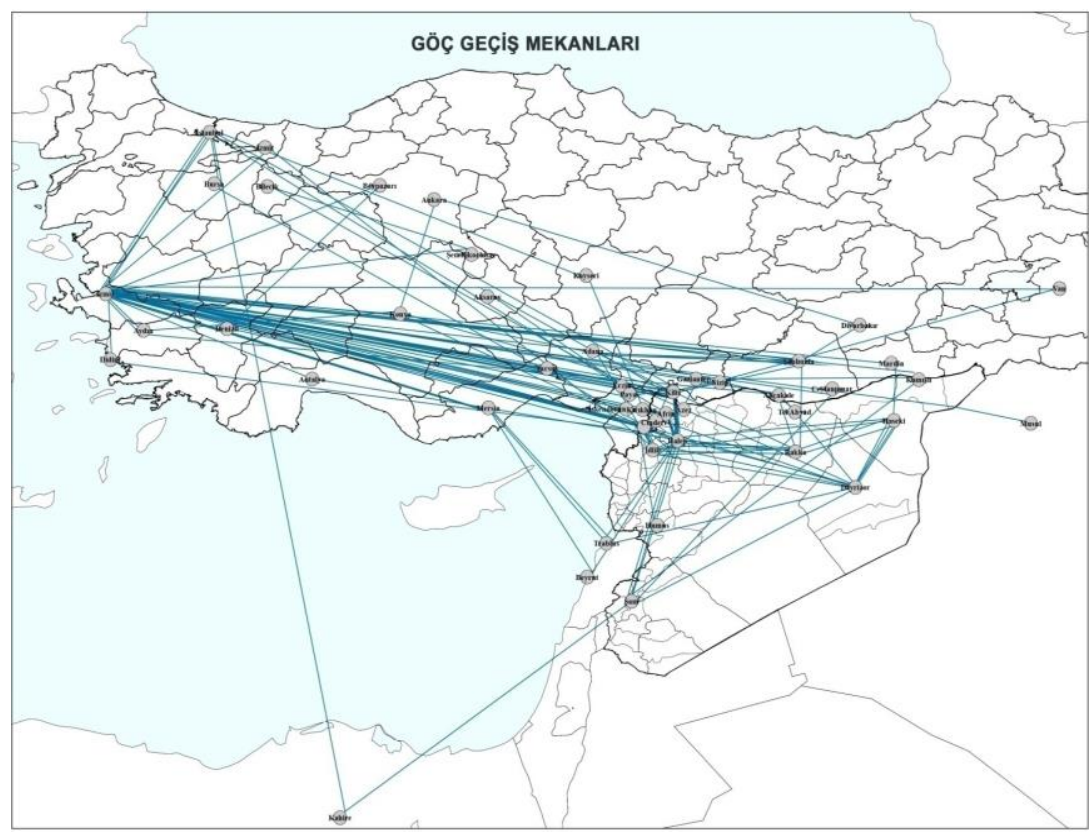

Şekil 4 İzmir'e Yerleşmeden Önce Yaşanılan İller

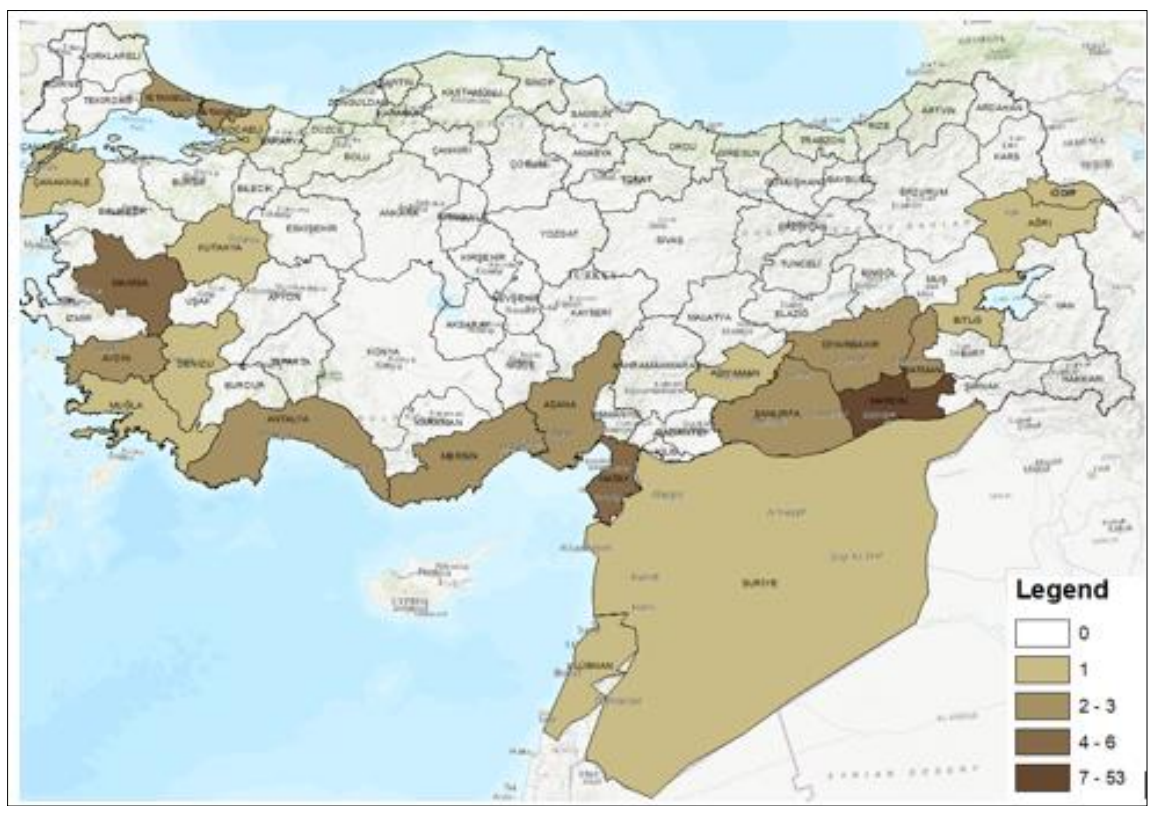

Grafik 1'de görüldüğü üzere İzmir, katılımcıların yaklaşık \%50'sinin Suriye'den çıkarken hedef olarak belirlediği kenttir. Verilen cevaplara bakıldığında herhangi bir hedef ülke ve kent seçmeden göç yolculuğunu başlatanların İzmir'i hedef olarak belirleyenlerin hemen ardında olduğu görülür. 
Grafik 1 Mültecilerin Göç Güzergâhında Varmayı Hedefledikleri Ülke/Şehir

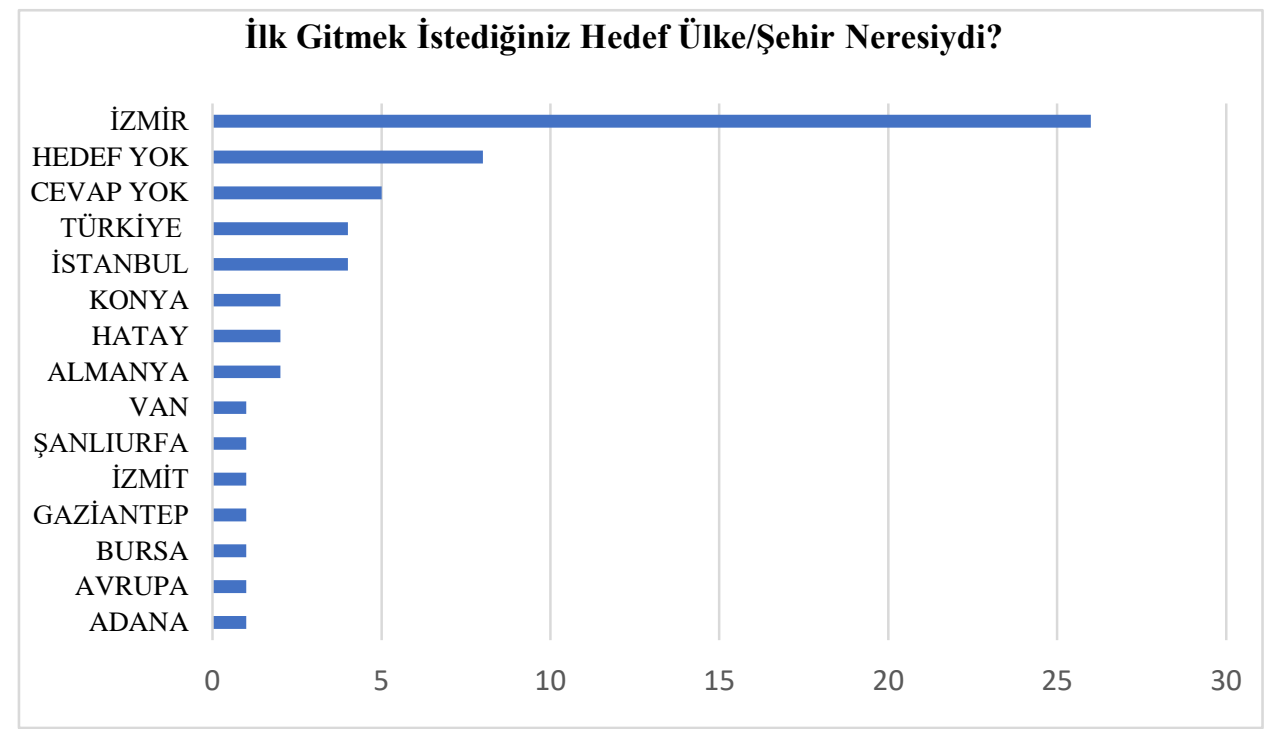

“İlişkiler Ağı Kuramı”, göçmen ilişkiler ağını, gelinen ülke ve hedef ülkelerde göçmenlerin, daha erken dönem göçmenlerin ve göçmen olmayanların arasında kurulan; akrabalık, arkadaşlık ve ortak köken ilişkilerine dayanan kişiler arası bağlar olarak tarif etmektedir (Massey vd., 1993, s. 148). İlişki ağları genişledikçe göç sürecinin göçmenler açısından kolaylaştığı ve olası risklerin azaldığı ifade edilmektedir (Massey vd., 1993, s. 149). Türkiye'de yaşayan Suriyeli mültecilerin yerleşim tercihlerini ilişkiler ağı kuramı çerçevesinde inceleyen bir çalışmada da kuramın varsayımlarının doğrulandığı sonucuna ulaşılmıştır (Çalışkan, 2020, s. 1202). Dil birliği, akrabalık ilişkileri, coğrafi köken birliği ve etnik birlik gibi nedenler, İzmir'in de aralarında bulunduğu, Türkiye'deki çeşitli kentleri kitlesel göç ile Suriye'den gelen kent mültecileri için "hedef kent" haline getirebilmiştir (Karakaya Ayalp, 2020; Özbakır vd., 2021). Benzer şekilde mevcut araştırmamızda elde edilen veriler, İlişkiler Ağı Kuramının önermiş olduğu gibi, İzmir'in hedef kent olarak seçilmesinde belirleyici olan en temel unsurların başında, kente daha önceden yerleşmiş olan akrabaların ve tanıdıkların varlığı gelmektedir (Grafik 2). Görüşmeciler de bu durumu destekleyen ifadelerde bulunmuşlardır: "Çıktığımızda hedefimiz İzmir diye bir düşüncemiz yoktu. Ama akrabalar İzmir'e yönlendirdiler" (Görüşmeci 1, 03.11.2018). İzmir'in tercih edilme sebeplerine baktığımızda akrabalık bağlarının varlığı nedeniyle kentin seçilmesinin yanında mahalle ölçeğinde ucuz barınma olanağı ve iş imkânları sağlaması da önemli etkenlerdendir ve görüşmeciler tarafından ifade edilmiştir. İş imkânlarının İzmir'i tercih etmesindeki rol bir görüşmeci tarafından "İzmit'te iş yoktu. Kız kardeşimin çocuğu, yeğenim, İzmir'e gel dedi. Burada daha çok iş var diye. O sebeple geldim.” (Görüşmeci 2, 03.11.2018) biçiminde aktarılmıştır. Giriş başlığı altında vurguladığımız İzmir'in Avrupa'ya "geçiş mekânı" işlevi ise katılımcılardan dördünün kenti tercih nedenini oluşturmaktadır. Katılımcıların hedef kent ve tercih nedenlerine ilişkin sonuçlar aşağıda görselleştirildiği gibi sıralanmaktadır. 
Grafik 2 İzmir'in Mültecilerce Tercih Edilme Sebepleri

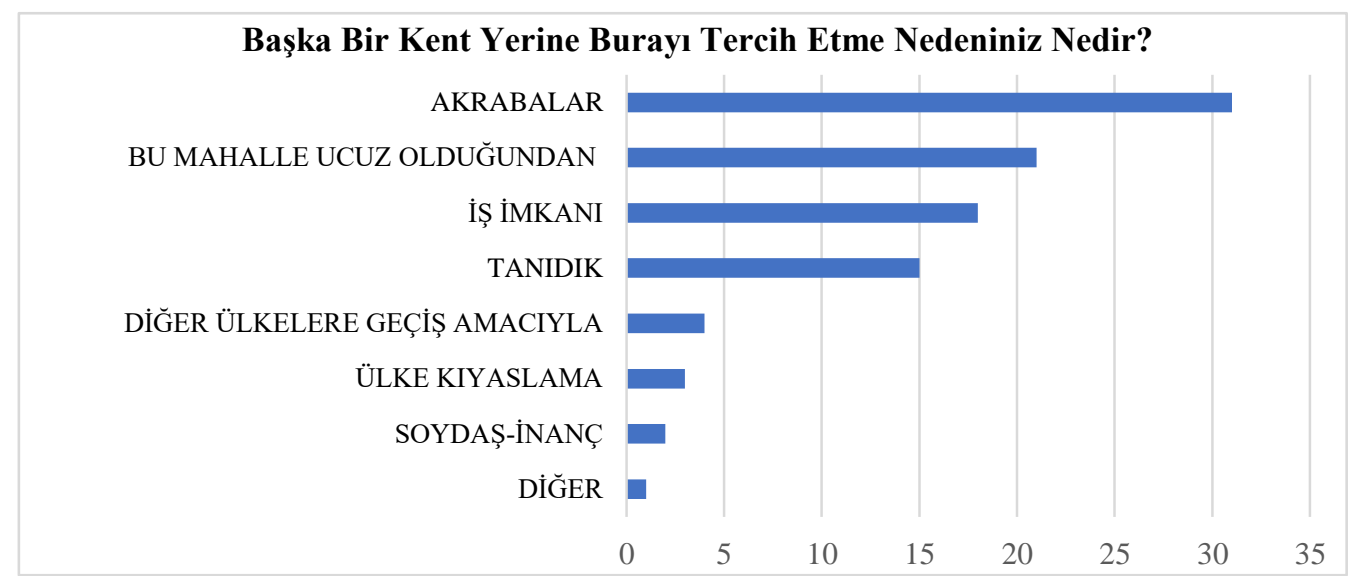

Katılımcıların kentte kalıcı bir yerleşim kurma yönündeki tasarımlarına ilişkin bulgular geri dönüş fikrinin ön planda olmadığını göstermektedir. Katılımcıların geleceğe dönük beklenti ve planları ölçeğinde kalıcılık meselesi "gelecek kuşakların burada yaşamasını isteme", "geri dönüş niyeti", "Türkiye'de kalma-başka ülkeye gitme düşüncesi” ve "kente yatırım yapma isteği” soruları aracılığıyla incelenmiştir.

Grafik 3 Gelecekte Türkiye Dışında Yaşanması Düşünülen Yer(ler)

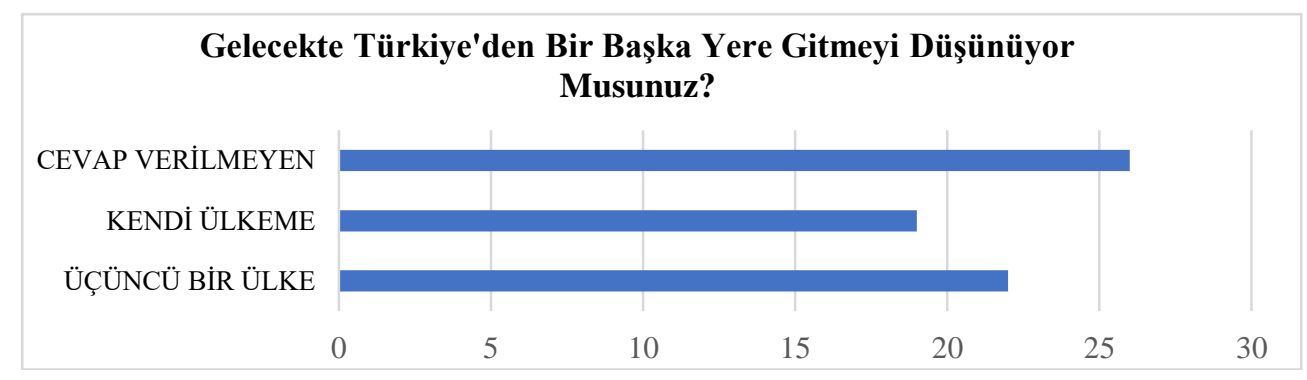

Sonuçlar, katılımcıların önemli bir bölümünün ülkede ve kentte kalıcı bir gelecek kurguladığını ortaya koymaktadır. "Gelecekte Türkiye'den başka bir ülkeye gitmek istiyor musunuz?" sorusuna katılımcıların neredeyse yarısı cevap vermemiş olsa da gelinen ülkeye geri dönmek, gelecek kuşakların Türkiye'de/İzmir'de yaşaması, kalıcılık ve kentte yatırım yapma yönündeki sorulara verilen cevaplar kalıcılığı işaret etmektedir. Bu istek görüşmecilerden biri tarafından "Buradayız artık geri dönmek istemem Suriye'ye... Burada ailem kök salsın isterim" (Görüşmeci 3, 03.11.2018) sözleri ile ifade edilmiştir. Kalıcılığa ilişkin sorulara verilen yanıtlar aşağıda Grafik 3'te ve Grafik 4'te görülmektedir. Grafik 3 'te kendi ülkesine ve üçüncü bir ülkeye geçiş ile ilgili yanıtlara rastlansa da Grafik 4'te görüşmecilerin \%90'ının Suriye'ye dönmek istemediği ve en az \%50'sinin İzmir'de ve Türkiye'de kalmayı hedeflediği görülmektedir. 
Grafik 4 Kentte Kalıcılığa İlişkin Sorular ve Cevapları

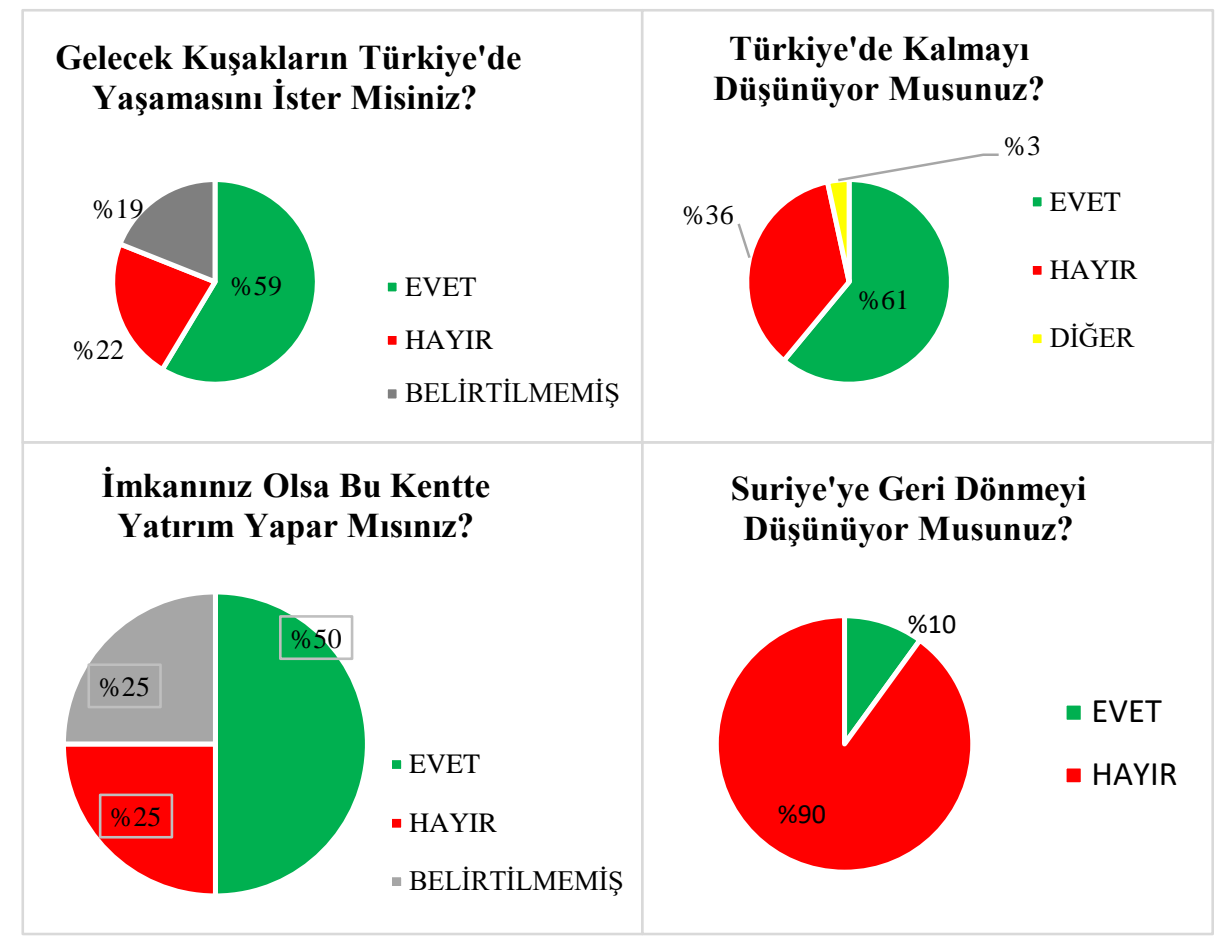

\subsection{Emek Piyasası ile Kurulan İlişkiler}

Göçmen ve mülteci istihdamı alanında yapılan pek çok çalışma, ekonomik süreçlerde yaşanan dezavantajlılıkları ortaya koymaktadır. Mülteciler arasında işsizlik, baş edilmesi gereken birincil problemlerdendir. Ancak ücretli bir işte çalışmak, göçmenler açısından pek çok sorunun da başlangıcıdır. Suriyeli mülteciler, emek piyasasında yerli halkın tercih etmeyeceği ölçüde düşük gelirli ve statülü, nitelik gerektirmeyen, tehlikeli, kirli, emek yoğun, güvencesiz ve kayıt dişı alanlarda iş bulabilmektedir (Adar, 2018, s. 14; Akbaş ve Ulutaş, 2018, s. 174; Kaygısı, 2017, s. 3). Suriyelilerin Türkiye işgücü piyasasında inşaat, tarım, sanayi ve ticaret sektörlerinde ücretli ve bağımlı konumda yer aldığı; ancak aynı işte çalışan yerli işçilerden daha düşük ücretle, vasıf düzeyini yansıtmayan ve hak gaspına uğradıkları işlerde çalıştıkları ifade edilmektedir (Lordoğlu ve Aslan, 2016, s. 793). Suriyeli ve yerli işçilerin benzer ekonomik etkinlik alanlarında yer bulma arayışları onları karşı karşıya getirmekte ve bir rekabet alanı yaratmaktadır. Yoksul grupların, yoksulluktan kurtularak nöbeti yeni yoksullara devretmesi olarak tanımlanan "nöbetleşe yoksulluğun" yerini "yoksulların rekabetinin” aldığı ifade edilmektedir. Yaşanan bu rekabetin özneleri olarak, yoksulluk nöbetini aynı anda tutan, farklı etnik kökene sahip yerli işçiler ve göçmen işçilere işaret edilmektedir (Kalkınma Atölyesi, 2016, s. 27). Çetin (2016, s. 1004-1011), Suriyeli mültecilerin toplumsal uyum sürecinin temel şartlarından biri olarak ele aldığı "ekonomik entegrasyonun" önündeki engelleri; çalışma izni, işsizlik, düşük ücret ve ücret gaspı olarak sıralamaktadır. Benzer şekilde Kaygısız (2017, s. 3) Suriyelilerin, çalışma hayatında maruz kaldıkları olumsuz koşullarla baş edebilecek yasal zeminden yoksun olduklarını vurgulamaktadır.

Araştırmamızda, görüşmecilerin İzmir'de iş piyasasına hangi koşullar çerçevesinde eklendiği işin niteliği ölçeğinde; çalışılan sektör, işten elde edilen aylık gelir, sosyal güvence ve mesai koşulları açısından incelenmiştir. Katılımcılardan 38'i herhangi bir işte çalışmamaktadır. Bu nedenle emek piyasasıyla ilişsili kimi sorular çalışmayan katılımcılarla yapılan görüşmelerde hane halkından çalışan üyenin çalışma deneyimlerine dayalı olarak sorulabilmiştir. Emek piyasasına ilişkin bulguların, Suriyeliler açısından Türkiye'de çalışma hayatına dair önemli bilgiler sunduğu gözlenmiştir. Bulgular katılımcıların büyük ölçüde emek yoğun işlerde, düşük gelirli ve statülü, 
güvencesiz ve kayıtsız çalıştığını göstermektedir. Çalışılan sektörler çoğunlukla hizmetler sektörüne bağl1 hurdacılık, garsonluk, servis elemanlığ 1 gibi nitelik gerektirmeyen iş kollarıdır. Suriye'de bir meslek ya da zanaat sahibi olan bireylerin de Türkiye'de ya parça başı işlerde ya günübirlik işlerde çalıştıkları ya da görece uzun süreli istihdam edildiklerinde diğer çalışanlardan çok daha ağır koşullarda ve daha uzun sürelerde çalıştıkları görülmektedir. Çalışma hayatına dönük koşulları bir görüşmeci şöyle aktarmıştır;

"Suriye'de tamircilik yapardım, dükkanım vardl. Bombardımanla beraber hem evimiz hem dükkanımız yılkldl. Sadece klyafetlerimizi alarak yola düşmek zorunda kaldlk. Halep'ten Afrin'e gittik, savaş orada da rahat vermedi. Mecburen Kilis'e gelmek zorunda kaldık... Manevi olarak hayatımız 180 derece değistiti. Tüm Suriyeliler gibi sadece klyafetlerimizle geldik. Psikolojik destek alamadık...İzmir' e geldik çünkü İstanbul büyük şehir, çok kalabalık. Kaybolsan yardım edecek kimse yok, hak ihlali daha fazla. Ev sahibin tanrı, iş veren daha zalim, daha kötü, şartlar daha ă̆ır her anlamda... Burada dil sorunum olduğu için iş bulamıyorum. Daha önce bir ütücüde çalı̧̧ıyordum. Akşam çılkınca da tamir işlerine gidiyordum. Şimdi ütü işi de yok tamir işi de. Inşaatta günlük işler yapıyorum. Ütücüde bazen 13 saat çalışıp en ağır işleri yapıp Türk çalışanlardan daha az allyordum" (Görüşmeci 4, 28.10.2018).

Görüşülen hanelerdeki çocukların \%35'inin işgücüne katıldığı ve hane toplam gelirlerinin katılımcıların \%90'ında asgari ücretin altında olduğu da diğer çarpıcı bulgulardır. Katılımcıların iş kollarına göre dağılımı grafik 5 'te gösterildiği gibidir. İş piyasası ile kurulan iliş̧kinin geçici, güvencesiz ve meslek sahibi ya da eğitimli olan Suriyeli sığınmacılar için dahi niteliksiz iş kollarında istihdam edilmek biçimindedir. Bunun yanında istihdam biçimi kısa süreli, iş değiştirmeye dayalı ve belirsizdir. Katılımcılardan lisans düzeyinde eğitime sahip olan bir görüşmecinin de ifade ettiği gibi; "Ben ve eşim çalışıyoruz. İlk geldiğimde tütün sarma ve dikiş işinde çalıştım, şimdi ise haftanın 3 günü evde okula giden çocuklara Arapça dersi veriyorum. Ayrıca bir kurumda gönüllü olarak çalışıyorum" eğitim durumundan da bağımsız olarak parça başı ya da kısa süreli istihdam şekli yaygındır (Görüşmeci 5, 20.11.2018).

\section{Grafik 5 Görüşmecilerin Çalıştıkları Sektörler}

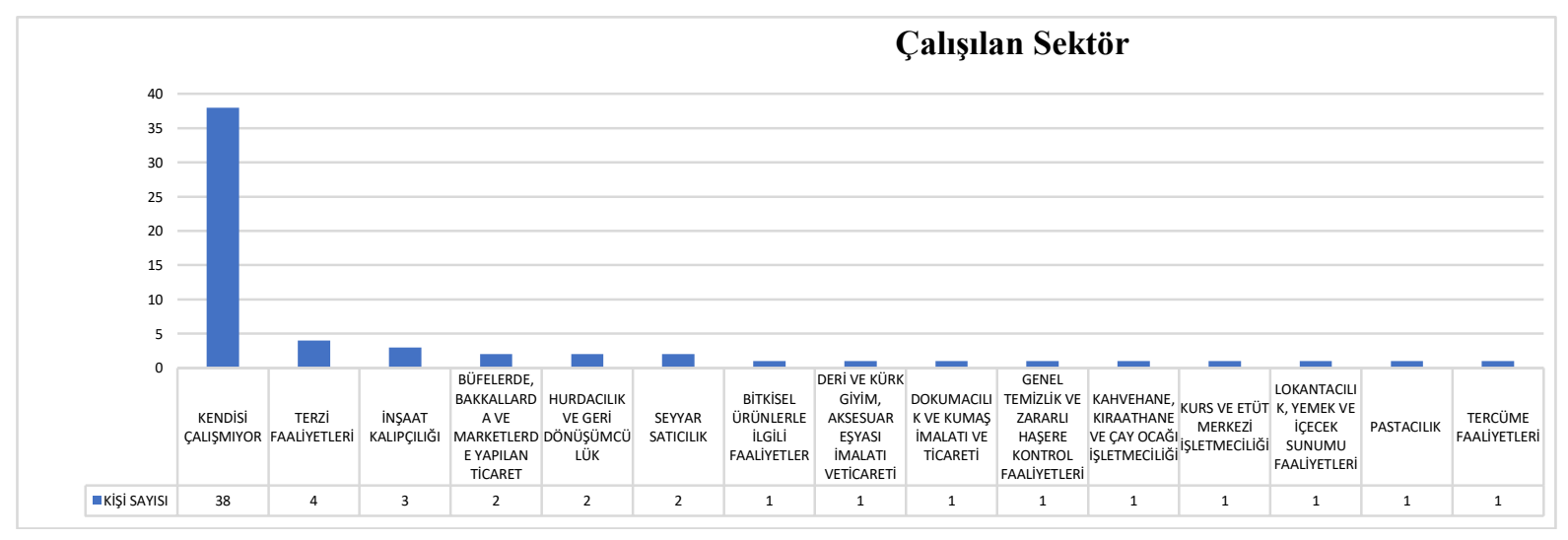

Yapılan işten elde edilen aylık gelir incelendiğinde, örneklemin büyük bir bölümünün asgari ücretin atında ücretler karşılığında çalışmakta olduğu anlaşılmaktadır. 
Grafik 6 Mültecilerin Çalışmakta Oldukları İşlerden Elde Ettikleri Aylık Gelir

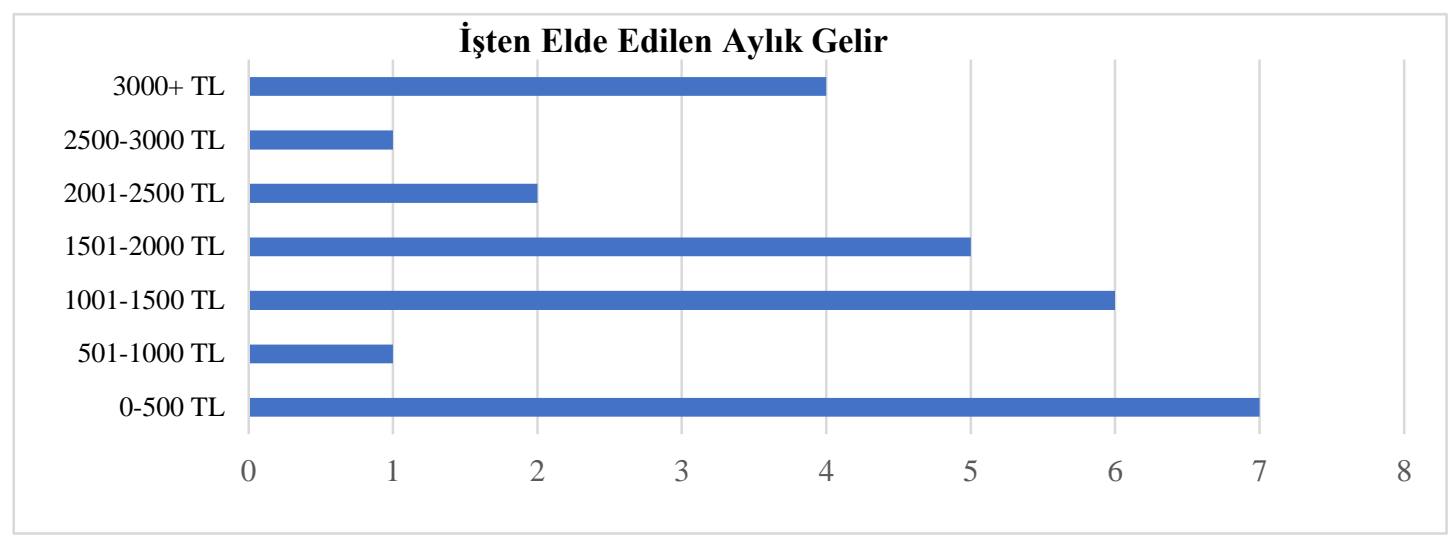

Düşük gelire rağmen, mesai saatlerinin azami haftalık çalışma süresinin üzerinde olması, Suriyelilerin piyasada ucuz iş gücü olarak kullanıldıklarının göstergesidir.

Grafik 7 Mültecilerin Çalışmakta Oldukları İşlerde Haftalık Çalışma Süreleri

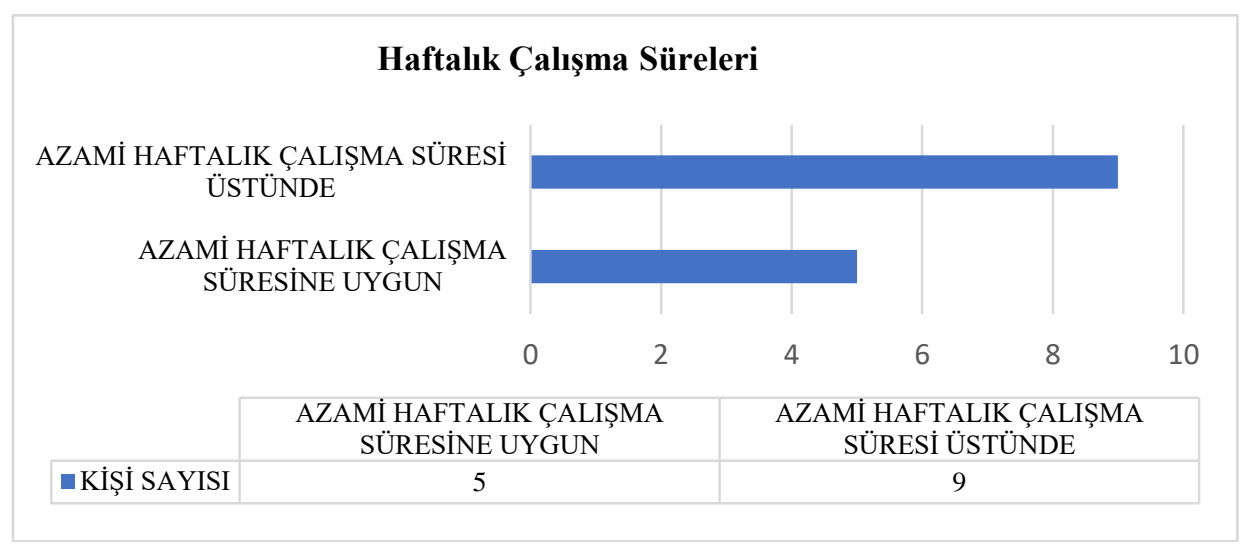

Ek olarak, Suriyeli katılımcıların iş sahasında kalıcı ve düzenli bir iş bulmakta zorlandıkları, aylık gelire bağlı işlerden çok günlük ya da parça başı işler bulabildikleri anlaşılmaktadır. Bu durum, çalışma süresi ile birlikte ele alındığında, süreksiz istihdamın kalıcılaştı̆̆ını ve nöbetleşe istihdamın yaygınlaştığını da göstermektedir. 
Grafik 8 Mültecilerin Çalışmakta Oldukları İşlerin Sürekliliği

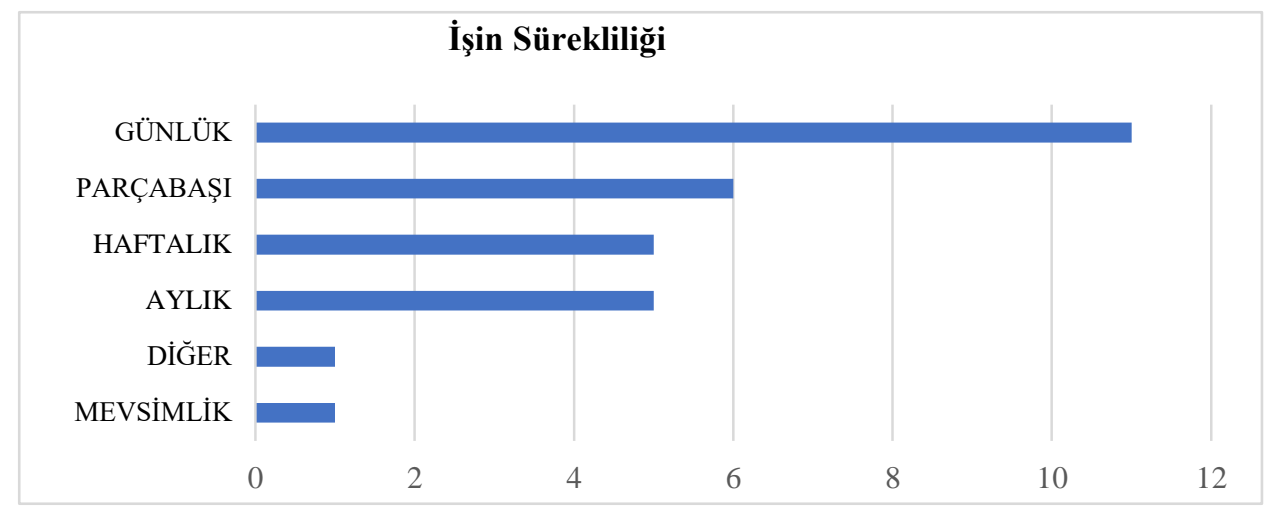

Katılımcılardan yalnızca biri, çalıştığı işin sigortalı ve çalışma iznine tabi olduğunu bildirmiştir. Görüşmelerde elde edilen veriler, bu koşulların emek ve hak ihlallerine zemin yarattı̆ı̆ıı göstermektedir. Ayrıca görüşmelerin \%97'si Türkiye'de çalışma izni alamamış ve enformel olarak istihdam edilmekte, yine \%97'si sigortasız çalışmaktadır.

\title{
2.3. Kent Hakkı, Barınma, Kent/Mahalle ile Kurulan İlişskiler ve Kentsel Hizmetlere Erişim
}

\author{
2.3.1. Kent Hakkı ve Barınma
}

Harvey (2013, s. 44)'e göre kent hakkı "şehrin barındırdığı kaynaklara bireysel veya kolektif erişim hakkı" ve "şehri değiştirme ve yeniden icat etme hakkı"dır. UNESCO tarafından 20 Avrupa kentinde yapılan araştırmaya göre, mültecilerin kentlere ilk vardıklarında karşılaştıkları en kritik ve temel insani sorunlar barınma, eğitim ve istihdamdır (UNESCO, 2016, s. 47). Bu bölümde; barınmaya erişim, kentsel hizmetlere erişim, mahalle ve kent ölçeğinde kamusal alan kullanımı ve tercihi, toplumsal yaşama dahiliyeti zorlaştıran ayrımcılık gibi hususlar irdelenmiştir. Suriyeli mültecilerin mahalle ve kent ölçeğinde kurdukları sosyal, toplumsal ve mekânsal ilişkilerin anlaşılması amacıyla katılımcılara yöneltilmiş olan bir dizi soru bu bölümde ele alınmıştır.

Mahalle ölçeğinde fiziksel ilişkinin birimlerinden biri olan konut meselesi, mültecilerin mekân ile ilişkisini mikro düzeyde incelemek ve barınma şartlarını anlamak bakımından önem taşımaktadır. Maslow'un ihtiyaçlar hiyerarşisi kuramında barınmak; fizyolojik bir temel ihtiyaçtır (Anbarcı vd., 2011, s. 292). Balkır (2010, s. 342) konutu, "bireye ait kişisel bir mekân; ikamet edenin kentsel varlığının temel simgesi ve toplumun temel yaşama birimi" olarak tarif etmektedir. Konut hakkının uluslararası hukukta dayandığı bildirgeler, sözleşmeler; ulus düzeyinde anayasal ve yasal hükümler bulunmaktadır. HABITAT III (2014, s. 33)'e göre, konut, özel mülk, barınma ve kentli hakları bir arada düzenlenmesi gereken haklardır ve bu yolla kentsel dönüşüm sürecinin yaşanabilirlik ilkeleri çerçevesinde gerçekleştirilmesi önerilmektedir. Dar gelirlilerin anayasal bir hak olan konut hakkına daha kolay ulaşılabilmesi yönünde birtakım yeni finansman modelleri üretilmesi gerektiği ifade edilmektedir (HABITAT III, 2014, s. 37). Aynı toplantıda dar gelir grubuna yönelik kiralık konut modellerinin mülk konuta alternatif olarak desteklenmesi, çözüm yollarından biri olarak ele alınmış, kooperatifçiliğe engel teşkil eden unsurların kaldırılması ve konut piyasasına yeniden kazandırılması ihtiyacı vurgulanmıştır (HABITAT III, 2014, s. 43). Bu tartışmalar çerçevesinde bakıldığında, kent yoksulları, mülteciler ve diğer kırılgan gruplar için barınma hakkına yönelik kamu eliyle geliştirilmiş politikalar olmadığını, geçici koruma statüsünün mülk edinmenin önünde çeşitli engeller oluşturduğunu, konut ve kiralık konut piyasası ile ilgili yasal düzenlemelerin yetersiz kaldığını ve serbest piyasa ekonomisinin koşullarına terk edilmiş olduğunu görmekteyiz. 
Katılımcıların, sağlıklı, karşılanabilir ve yaşanabilir bir konuta erişim konusuna yönelik olarak görüşmelerde sorulan sorulara verilen cevaplar katılımcıların yaşadıkları konuttan büyük ölçüde memnun olduklarını göstermektedir. Ancak, konutun sıkıntılarına yönelik verilen cevaplar göstermektedir ki konutların altyapı, sıhhi koşullar, açık alan, genişlik, köhneme ve bunun gibi çok sayıda sorunu vardır. Oturulan evin mülkiyet durumunun bütün katılımcılarda kiralık olduğu, aylık kira bedelininse ekseriyetle 0-500 lira arasında değiştiği anlaşılmaktadır. Barınma mekânının sabitliğinin anlaşılması amacıyla katılımcıların mevcut konutta ne kadar süredir bulundukları sorulmuştur. Katılımcılar ağırlıklı olarak 0-6 aydır aynı konutta bulunduklarını ifade etmişlerdir. Katılımcıların İzmir'e varış tarihlerine ve toplam barınılan konut sayılarına bakıldığında, sıklıkla konut değiştirmek zorunda kalındığı anlaşılmaktadır. Bu durumun, Basmane'de ve özellikle Kapılar ve çevresinde konutlar arası hareketliliğin göstergesi olabileceği düşünülmektedir. Söz konusu yer değiştirmenin başlıca nedenlerinden biri olarak, çalışmanın yürütüldüğü dönemde, çalışma sahası olarak seçilen çok sayıda mahallenin kentsel dönüşüm proje alanı olması gösterilebilir. Özellikle Kadifekale ve civarında kentsel dönüşüm nedeni ile yıkım bekleyen konutların görece daha ucuza kent mültecilerine kiralandığ ve bu konutlarda ortalama üç ay süreyle barınıldığ görülmüştür. İkinci olarak Basmane semtindeki konutların eski ve köhne olmasının bu durumda belirleyici rol oynadığı düşünülmektedir.

Grafik 9 Oturulan Konutun Aylık Kira Bedeli

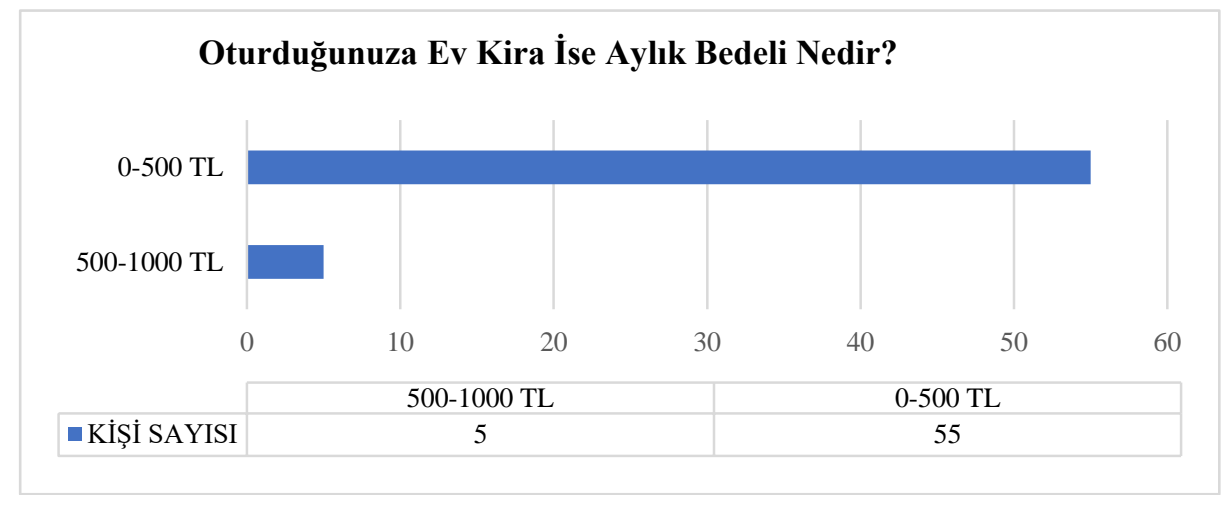

Çalışma alanında kent mültecilerinin yoğun olarak yaşadıkları mahallelerde kiralık konut piyasasında 2012 yılından sonra Suriye'den gelen yoğun göç dalgası ve talep artışının dramatik bir değişiklik yaratmadığı görülmüştür. Konut arzı artmazken konut talebinin artış gösterdiği böylesi bir durumda kiralık konut fiyatlarında kayda değer bir değişiklik yaşanmamasının üç nedeni vardır. Bunlardan ilki yukarıda bahsedildiği üzere halihazırda boş olarak yıkım bekleyen kentsel dönüşüm alanındaki konutların geçici sürelerle kiralanmasıdır. Kentsel dönüşüm, konut ve barınma ilişkisindeki geçicilikle ilgili "Bu mahallede tam 11 tane (ev) değiştirdik. Bu eve de 10 gün önce taşındık ama evin yıkım kararı var. 2 ay sonra yıkılacak. Daha istikrar sağlayabileceğimiz bir yere gitmek isterim” (Görüşmeci 6, 10.11.2018) görüş̧meci ifadesi durumu ortaya koymaktadır. Bir diğer neden, yine içinde yaşayanların olmadığı köhnemiş konutların da kiraya verilmesidir. Çalışma alanının belirli bölgelerinin kentsel sit alanı olması ve mülk sahiplerinin yapıları yenileyebilecek bir ekonomik kaynağa sahip olmaması tescilli konutların bir kısmının metruk biçimde ve boş kalmasına neden olmaktadır. Tarihi ve tescilli konutları da kapsayan bu "kiralık konut arzı" biçiminin yapıların tarihi niteliğine nasıl bir etki yaptığı henüz bilinmemektedir. Son neden ise, yapıların iç mekanlarının birden fazla bağımsız bölüme dönüştürülerek birim sayısının arttırılmış olmasıdır. Alanda bu üç durum da gözlemlenebilmektedir.

Kiralık konut arzı arttırılmış olsa da kent mültecileri kiralık konut bulmakta çeşitli nedenlerle zorluklar yaşamaktadır. $\mathrm{Bu}$ noktada, mahalle ile kurulan hem fiziksel hem de sosyal ilişkiler hakkında önemli fikirler veren bir başka alt başlığa, "konut arama sürecinde yaşanan zorluklara" değinmek önemlidir. Bu başlık, bir yanıyla Suriyeli mültecilerin 
barınma ihtiyacını karşılama yönündeki sorunlarına işaret ederken, bir yanıyla da Türkiyeli semt sakinlerinin Suriyelilere karşı tutumunu yansıtmaktadır. Öyle ki katılımcılara ev ararken karşılaştıkları temel zorlukların neler olduğu sorulduğunda, katılımcıların sorunlarını büyük oranda "ev vermek istenmiyor" şeklinde ifade ettikleri görülmektedir: "Suriyeli olduğumuz için ve çok çocuklu ailelere bazı ev sahipleri ev vermiyor" (Görüşmeci 7, 02.11.2018). Yanı sıra, konut bedelinin üstünde ücretler ve niteliği daha düşük olan konutlar da kiralık konuta erișim bakımından yaşanan diğer zorluklardır.

Grafik 10 Kiralık Konut Ararken Karşılaşılan Zorluklar

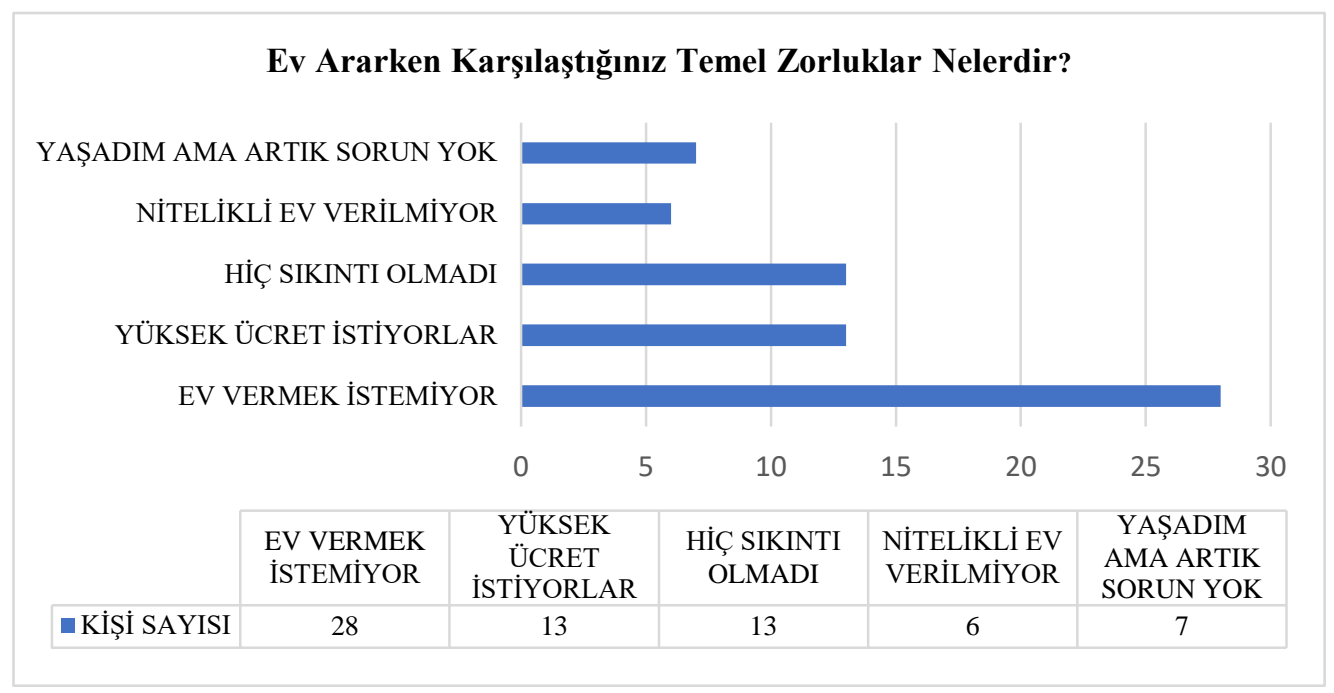

\subsubsection{Kentsel Hizmetlere Erișim}

Nüfus verilerine göre en kalabalık Suriyeli nüfusu barındıran sekizinci il olma özelliği taşıyan İzmir ilindeki Suriyeli kentsel mültecilerin, yerel yönetimlerin gündeminde yer alması kaçınılmazdır. Kentle kurulacak bağın önemli bir boyutunu temsil eden belediyelerin bu yeni ve geniş sosyal grubu nasıl konumlandırdığı, Suriyelilerin kentle kuracağ ilişkileri önemli ölçüde biçimlendirecektir. Yerel yönetimlerin Suriyeli mültecilere hizmet ulaştırma konusundaki sorumluluklarını "Hemșehri Hukuku" ve "Yabancılar ve Uluslararası Koruma Kanunu" dâhilinde ele alan Çamur (2017, s. 119-120), mültecilerin hizmet sunumu kapsamının dışında tutulamayacağını vurgulamaktadır. Araştırma sahamızın bağlı olduğu Konak Belediyesi ve İzmir Büyükşehir Belediyesi’nin mültecilere yönelik sunduğu hizmetleri listelemekte, bu hizmetlerin çoğunlukla maddi yardımlardan oluştuğunu ve kente yerleşmiş mülteci nüfusuna oranla oldukça sınırlı sayıda bireye ulaştığının altını çizmektedir (Çamur, 2017, s. 122).

Araştırmamız kapsamında Suriyeli mülteciler açısından yerel yönetimlerin ne ifade ettiğinin ve yerel yönetimlerle ne ölçüde temas içinde olduğunun anlaşılması amacıyla katılımcılara bir dizi soru yöneltilmiştir. Belirtmek gerekir ki, Suriye'de yerel yönetim sistemi Türkiye'dekinden farklıdır. Suriye'de idari kademelenme valilikler (örneğin; Şam valilik düzeyinde bir kenttir), "manātiq" (bölge olarak tanımlanan ancak daha çok mıntıka olarak çevirisi yapılabilecek alan) ve "nawāḥ̂̄" (alt bölge- alt mıntıka) olmak üzere üçe ayrılır (Syria- Local Government, 2021). "Muhāfiẓūn" biçiminde anılan valilerin kısmi de olsa idari olarak güçleri vardır ancak daha alt kademelerdeki yerleşmelerin yerel yönetim yapısı doğrudan merkezi hükümete bağlıdır. Saha çalışmalarında "belediye" kavramının karşılı̆̆ının Suriyeli kent mültecileri için valilik, "manāțiq" ya da "nawāḥ̂̉” biçiminde algılandığı düşünülmektedir. Türkiye'ye giriş yaptıktan sonra karşılaşılan ve ilişki kurulan ilk kurumun İzmir Valiliği İl Göç İdaresi olması ve kent 
mültecileri arasında "Göç İdaresi" olarak tanınıyor olması sebepleri ile "manāṭiq" ya da "nawāḥ̂" yapılanmalarına benzer algılanan belediyelerin Göç İdaresi'ne bağlı olduğuna yönelik bir algının yaygın olduğu düşünülmektedir. Bu alg1, kent mültecilerinin belediyelerin hizmetlerine, sorumluluk ve yükümlülüklerine dair ya fikir sahibi olmamalarına ya yanlış fikir sahibi olmalarına ya da sınırlı bir bilgileri olmasına neden olmaktadır. Aşağıda verilen cevaplar ve yapılan değerlendirme bu çerçeve düşünülerek ele alınmalıdır. Örneğin, "belediye hizmetleri" dendiğinde, görüşmeciler çoğunlukla sadece "su, elektrik ve çöp" ile ilişkilendirerek yanıt vermiştir.

Yaşadıkları kentte "belediyelerle" herhangi bir ilişki kurup kurmadıkları sorulan katılımcıların \%34'ünün bir şekilde belediyeye yolunun düştüğü anlaşılmaktadır. Diğer yandan \%60'ının belediyelerle ilişki kurmadığı görülmüştür. Belediyelerin hizmetinden duydukları memnuniyeti ise genel anlamda olumlu değerlendirdikleri görülmektedir.

Grafik 11 Belediyeler (Büyükşehir ve İlçe Belediyeleri) ile İlişki ve Belediye Hizmetlerinden Memnuniyet

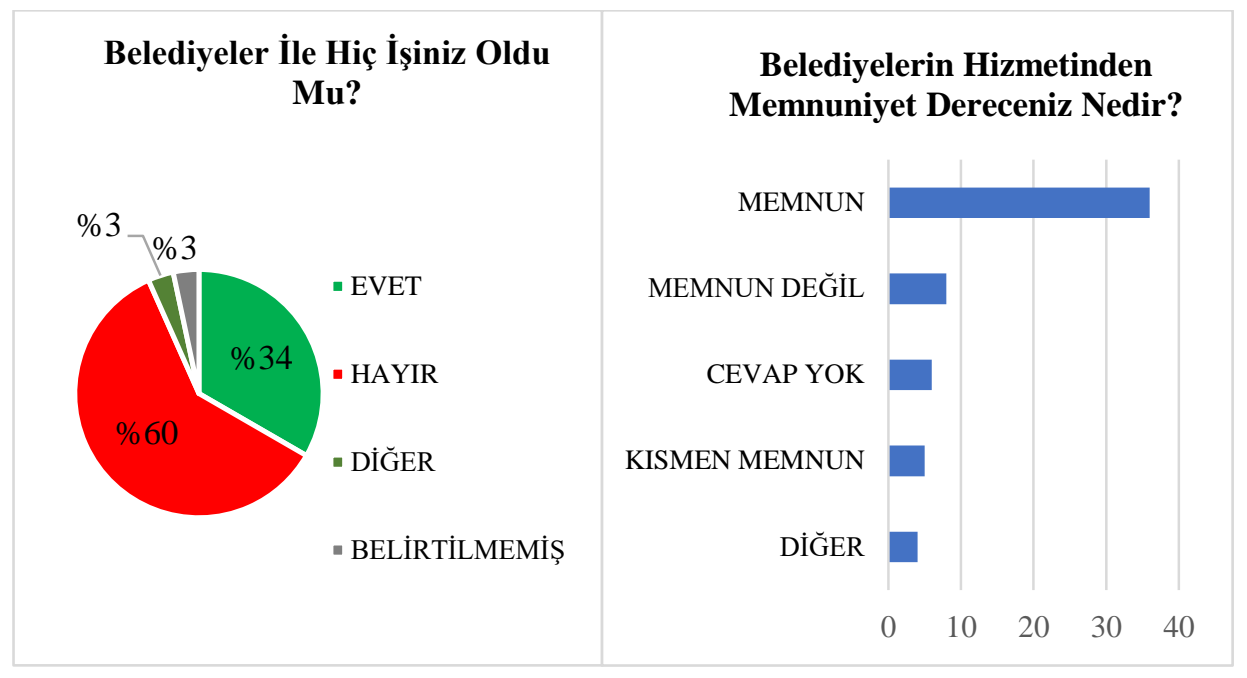

Kentsel hizmet alanlarının yeterliliğini değerlendirmeleri istenen katılımcıların bu alanları büyük ölçüde yeterli bulduğu görülmüsşür. Mahalle ölçeğinde karşılaşılan problemlerin neler olduğu sorusuna katılımcıların cevabı çoğunlukla "problem olmadı̆̆ı" yönündedir. En sorunlu biçiminde değerlendirilen konunun ise "güvenlik" ile ilişkili olduğu anlaşılmaktadır. Öte yandan, görüşmecilere mahalle ölçeğindeki eksiklikler sorulduğunda yeşil-açık alan ya da park ihtiyacı, eğimli arazide yaya olarak hareket etmenin zorlukları, toplu taşıma araçlarının sıklı̆ğındaki sorunlar vb. çok sayıda kentsel mekâna dair hizmet eksikliği ifade edilmiştir. Bu sorunlar Grafik 12'de de görülmektedir. Grafikte görüldüğü üzere, mahalle ölçeğinde yaşanan ortama ve kent içinde yaşam alanı tercihine dönük sorunları ve tercihleri belirleyen etmenlerden başlıcaları kentsel güvenlik, topoğrafik v açık alan ile yeşil alanların varlığı ve erişilebilirliği. $\mathrm{Bu}$ tercihlerini ve tercihe konu olan gerekçeleri aktaran görüşmecilerden birinin ifadesi aktarıldığı gibidir: "Eşrefpaşa ve Bozyaka'ya taşınmak isterim. Eşrefpaşa'da kardeşim oturuyor ve oralar daha düzayak. Ama kiraları biraz daha yüksek oraların. Ayrıca bu mahallede esrar içenler falan var. Torunumuz bunları öğrenmesin diye bile taşınabiliriz" (Görüşmeci 8, 16.11.2018). 
Grafik 12 Mahalle Ölçeğinde Karşılaşılan Sorunlar

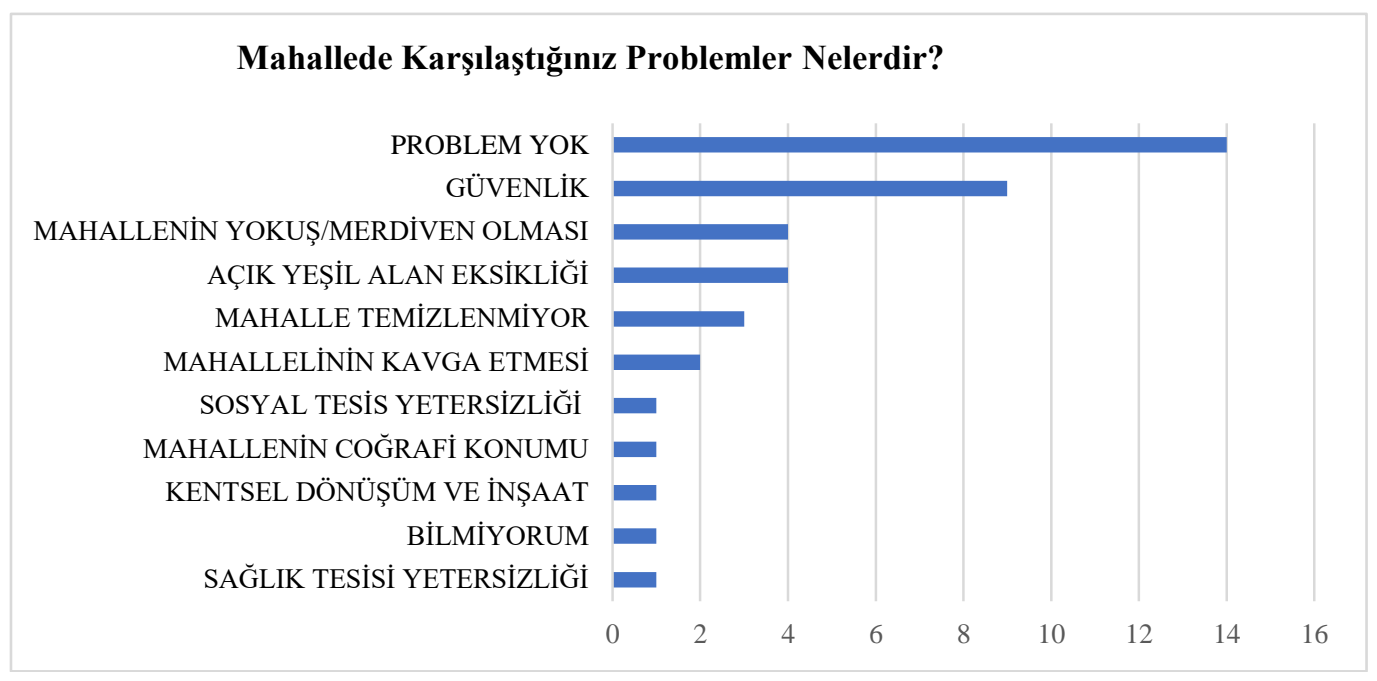

\subsubsection{Sosyal İlişkiler}

Allport tarafından ortaya atılan ve Pettigrew'in (1998, s. 66), katkılarıyla geliştirdiği "Gruplar Arası Temas" kuramı farklı sosyal gruplara mensup üyeler arasında belli koşullar altında gerçekleşen temasların, gruplar arası ilişkilerde olumlu sonuçlar doğuracağını iddia eder. Bu dört anahtar koşulu eşit statü; ortak hedefler, gruplar arası iş birliği; otoritelerin, yasaların ve geleneklerin desteği olarak sıralar. Bununla birlikte, gruplar arası yakın temasların, özellikle arkadaşlık ilişkileri söz konusu olduğunda, gruplar arasında olumlu tutumların ve duyguların gelişmesine katkıda bulunacağ ifade edilir (Pettigrew, 1998, s. 72). Bir diğer taraftan toplumsal yaşama katılım için kent mültecilerinin ve göçmenlerin ilk sosyal ilişkileri geliştirdiği yer kuşkusuz mahallelerdir. Bu nedenle, ilişkiler ağı kuramının tarif ettiği ve yukarıda da belirtildiği gibi, arkadaşlık, akrabalık ve tanıdıklık ağları göç edilecek kentin seçiminde, göç sonrası yeniden yerleşme sürecinde kurulacak ilişkilerin niteliğinde kritik role sahiptir. Bu bakımdan, mahalle ölçeğinde kurulan sosyal ilişkiler, arkadaşlık ilişkileri ekseninde ele alınmış ve Grafik 13 'te "arkadaşlık ilişkileri" biçiminde tanımlanmıştır. Elde edilen bilgiler; katılımcıların yaşadıkları mahallede arkadaşlarının bulunduğunu ve bu arkadaşların kimlik bakımından en çok Suriyeli, ikinci olarak Türkiyeli olduğunu göstermektedir. Mahalleli ile kurulan ilişkinin niteliğinin değerlendirilmesi istendiğinde, katılımcıların büyük bölümünün bu ilişkiyi olumlu değerlendirdikleri görülmektedir.

Grafik 13 Suriyeli Kent Mültecilerinin Yaşadıkları Mahallede Bulunan Arkadaşlarının Milleti

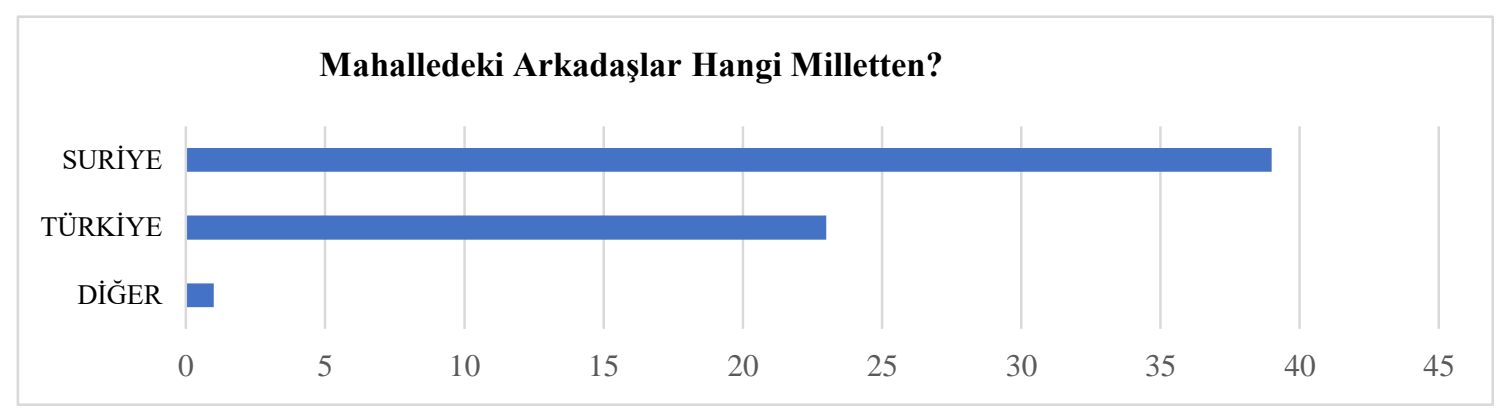


Göçmenlerin uyum süreçlerinde, ayrımcılığın önemli rolü bulunmaktadır (Sam ve Berry, 2010, s. 479). Ayrımcılık algısının ya da yaşantısının, göçmenlerin göç ettikleri kültürlere uyum başarısını önemli ölçüde etkilediği ortaya konmuştur (Berry ve Sabatier, 2010, s. 192). Görüşmeciler mahalle ölçeğinde ilişkilerini "olumlu” biçimde tarif etse de katılımcılara Türkiye'de herhangi bir alanda ayrımcılığa ya da dışlanmaya maruz bırakılıp bırakılmadıkları, maruz kaldılarsa bunun hangi alanda yaşandığı sorusuna verilen cevaplar sosyal alanda da ayrımcılığın söz konusu olduğunu göstermiştir. Katılımcıların \%32'si sosyal alanda ve okul, hastane gibi kamusal alanlarda bir ayrımcılık ya da dışlanma deneyimi ile karşı karşıya kaldığını ifade etmiştir. Görüşmecilerin kamusal alanda yaşadıkları ayrımcılık deneyimlerini aşağıdaki ifadelerle aktarmıştır:

"Hastaneye gidince beni (Türkçe bildiğim için) Türk sanıyorlar. Doktorlar neden Suriyelilere yardım ediyorsun pis bunlar diyorlar. Hastanede komşumun çocuğunun böbreğinde taş var. Hastaneye gittik; doktorlar Suriyeliler buraya geliyor, çok çocuk yapıyor, bizim askerler orada ölüyor. Komşum ağlamış en sonunda doktora "Biz de insanız" demiş. Burada yemin ettim bir daha çocuk yapmayacağım. Doktorlar bize yardımcı olacaklarına bize kızıyorlar, bize çok ihanet ettiler. Tepecik hastanesinde komşusu doğum sancısından bağırınca doktor tokat atmış bağırıyor diye. Çocuk hasta olunca korkumdan çocuğu hastaneye götüremiyorum. Eczaneden parayla ilaç alıyorum. Bize Suriye'den mikrop getirdin diyorlar. Otobüste Suriyelilere yaklaşmayın mikrop kaparsınız diye bağırıyorlar.” (Görüşmeci 9, 22.12.2018)

Grafik 14 Ayrımcılık ve Dışlanmaya Uğrama Durumu ve Ayrımcılığa Uğranan Alanlar

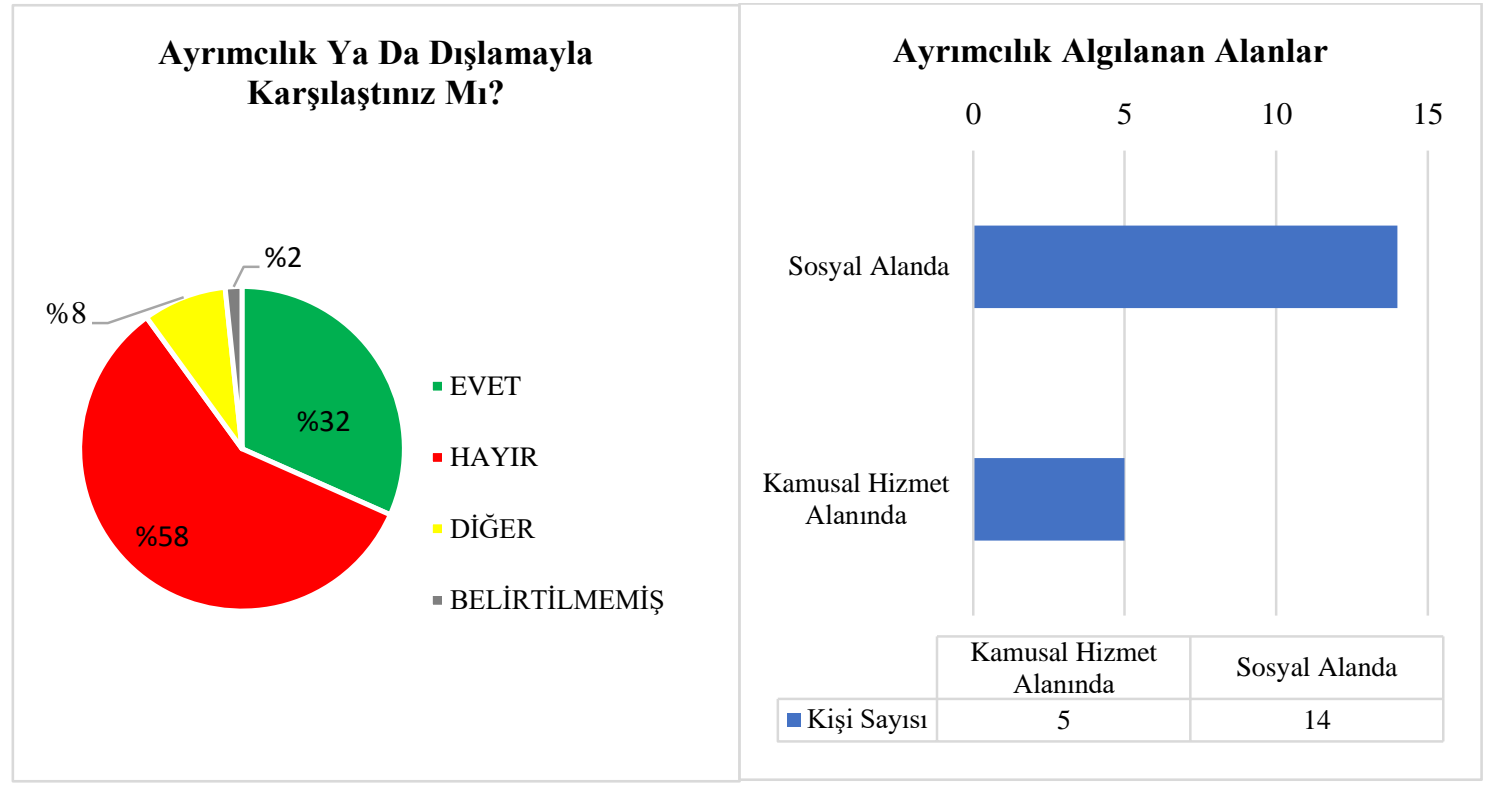

Mahalle ile kurulan ilişkinin mekânsal boyutunun analiz edilmesi amacıyla katılımcılara yaşadıkları ilçe/mahallede hangi mekânları sıklıkla kullandıkları sorulmuştur. Elde edilen verilere göre mekânsal ilişkilerin öncelikli olarak sağlık ve eğitim gibi kamusal hizmet, park alanı ve alışveriş gibi temel kentsel hizmetlere dayalı ihtiyaçlardan ve gündelik ihtiyaçlardan ileri geldiği anlaşılmaktadır. Ayrıca, görüşmecilerin kentte en çok ziyaret ettikleri kentsel kamusal alanın Kültürpark ve sahil şeridi olduğu görülmüştür. 
Grafik 15 İlçede ve Mahallede En Sık Kullanılan Mekanlar

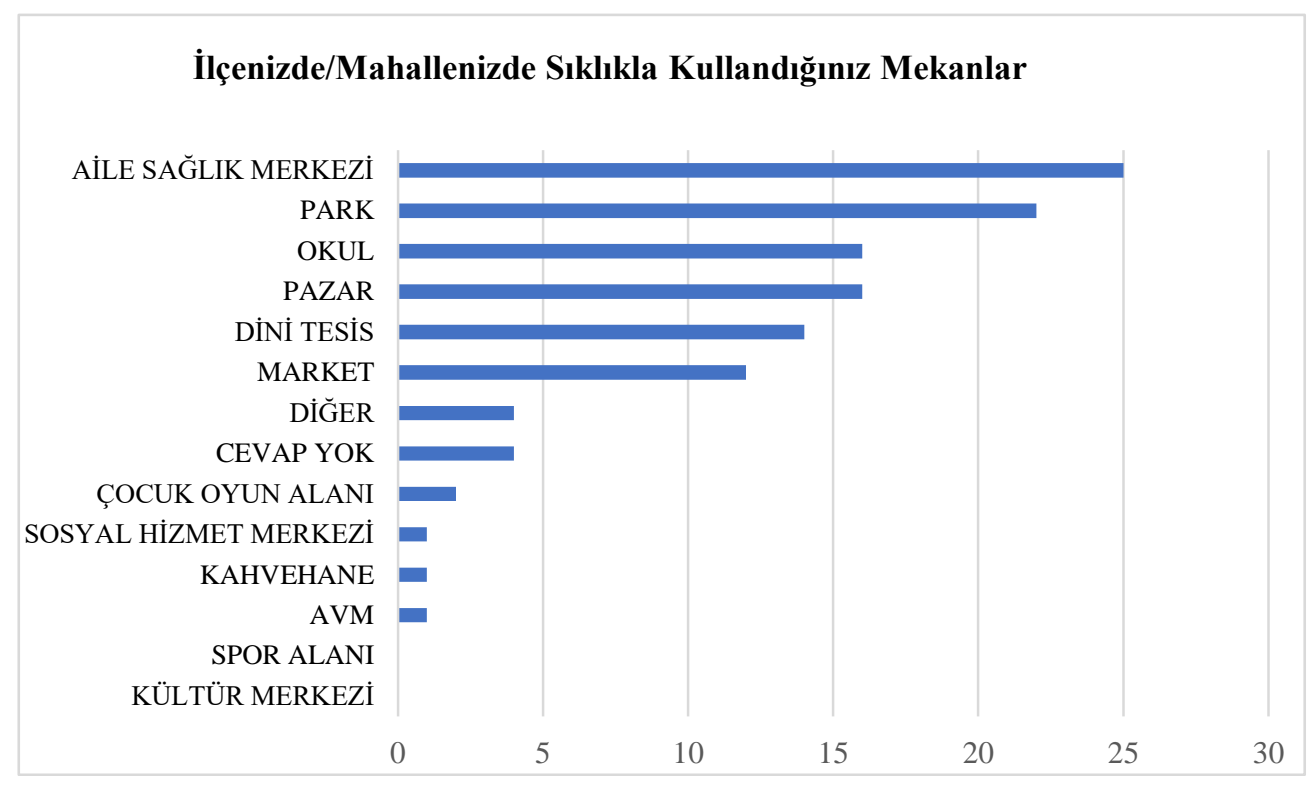

\subsection{Kamusal Hizmetlere Erişim}

Türkiye'ye göç eden Suriyelilerin önemli bir kısmını okul çağındaki çocukların oluşturması, dahası 2011'den beri devam eden süreçte Türkiye'de dünyaya gelen ve bugün okula devam edecek yaşa gelmiş çocukların varlığı, Suriyeli çocukların eğitim ihtiyacını göz önünde tutmayı gerektirmektedir. Türmen (2011, s. 13), en temel çocuk haklarından eğitim hakkının uluslararası sözleşmeler ve yasalarla güvence altına alındığını, afetler gibi acil durumlarda da sürdürülmesinin devletin zorunlu görevi olduğunu vurgulamaktadır. Aynı zamanda afet durumlarının, çocuğun psikolojik sağlığında travmatik izler bıraktığının, çocuğun bu zorlu sürecin üstesinden gelebilmesinde eğitimin önemli katkısı olacağının altını çizmektedir. İnsan eliyle yaratılmış bir afet olarak Suriye savaşı ve ardından gelen göç süreçlerinin de çocuklarda benzer etkiler yarattığını ifade eden Yavuz ve Mızrak (2016, s. 177) Türkiye'de Suriyeli çocukların eğitim koşullarını acil durumlarda eğitim çerçevesinde incelemektedir. Okula devam edemeyen 500 bin mülteci çocuğun varlığına, okula devam edenler açısındansa pek çok aksaklık ve yetersizliğe dikkat çekilmektedir. (Yavuz ve Mizrak, 2016, s. 194-195). Çalışmamızda, Suriyeli kent mültecilerinin kamusal hizmetlere erişim olanakları en temel düzeyde bulunan eğitim ve sağlık ihtiyaçları üzerinden sorgulanmıştır. Ailede okul çağındaki bireylerin eğitim alıp almadığı sorulmuş, alan bireyler açısından eğitimin kalitesini değerlendirmeleri istenmiştir. Katılımcıların \%41'i okul çağındaki aile bireylerinin eğitim alabildiğini, \%35'i ise alamadığını bildirmiştir. Eğitim alamayan okul çağındaki çocukların istihdama katılma ve ortaöğretim çağında eğitimin sürdürülmemesi nedenleriyle olduğu görülmüştür. Bir hanede ise İzmir'de İl Göç İdaresi ile kayıt sorunu yaşadığı için hanedeki çocukların eğitim alamadığ́1 görülmüştür. Eğitim hizmetlerinden memnuniyet derecesinin genel anlamda yüksek olduğu görülmüştür.

En temel insan haklarından biri de sağlık hizmetlerine ulaşım hakkıdır. Türkiye'de yaşayan Suriyelilere yönelik sağlık hizmetleri, Geçici Koruma Yönetmeliği kapsamında tanımlanmakta, Suriyeliler acil ve ikinci/üçüncü basamak sağlık hizmetlerinden geçici koruma kimlik belgesiyle ücretsiz yararlanmaktadır (Keleşmehmet, 2018, s. 121). Katılımcıların sağlık hizmetlerine erişim olanaklarının anlaşılması amacıyla, hanedeki çocukların aşı durumu, sağlık ihtiyaçlarının nerelerden ve ne şekilde karşılandığı sorulmuştur. Sonuçlar katılımcıların \%72'sinin sağlık hizmetlerine erişim sağlayabildiklerini; \%86'sı çocuklarının aşılandığını; sağlık ihtiyaçlarının en çok üçüncü kademe (araştırma hastaneleri, üniversite hastaneleri vb.) ve birinci kademe sağlık kuruluşlarından (aile sağlığı merkezleri) karşılandığını göstermektedir. Özellikle birinci kademe sağlık kuruluşlarını kullanmak görüşmeci kadın bireyler tarafından "kentsel yaşama ve toplumsal yaşama katılmanın önemli yollarından biri” olarak ifade edilmiştir. Kadınların kent içi 
hareketliliklerinde çocuklarının sağlık ihtiyaçlarını karşılamak üzere 3. Kademe sağlık kuruluşlarına yapılan ziyaretler önemli bir yer tutmaktadır.

\section{Grafik 16 Tercih Edilen Sağlık Kurum ve Kuruluşları}

\section{Sağlık Sorununuz Olduğunda Hangi Kuruma Gidersiniz?}

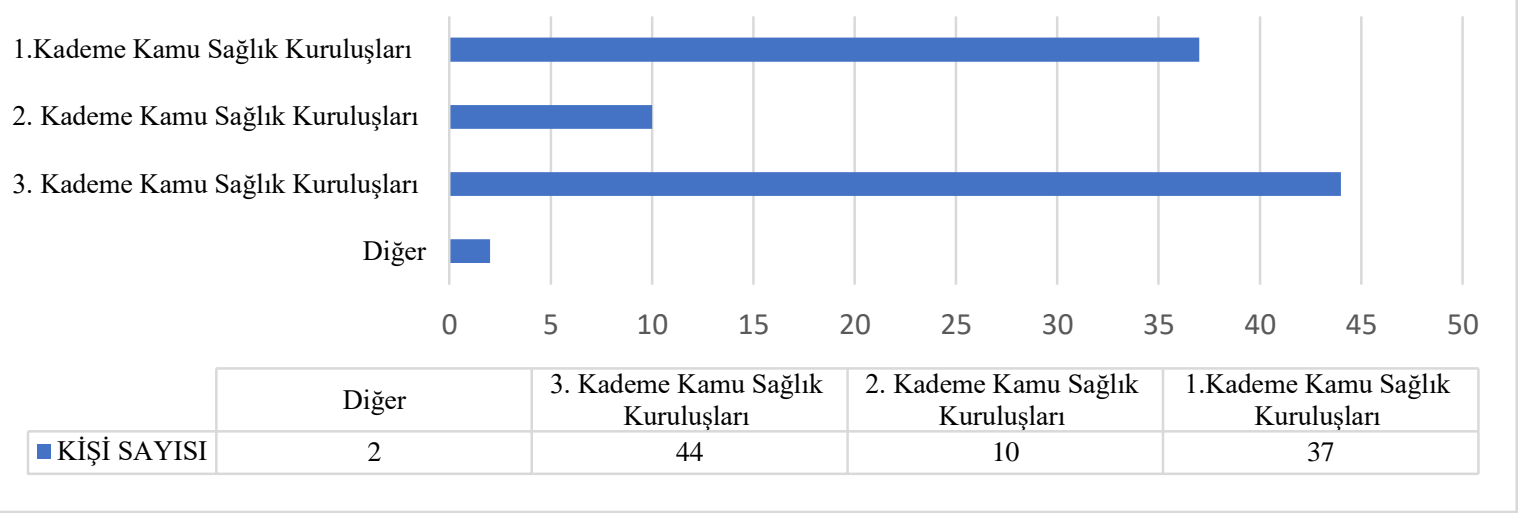

\subsection{Duygular, Kaygllar ve Beklentiler}

Kültürleşme (acculturation) kavramı Berry (2005, s. 698-699) tarafından, farklı kültürel grupların ve bu gruplara mensup olan bireylerin bir araya gelmesinin neticesinde, gruplarda gerçekleşen karşılıklı kültürel ve psikolojik değişimler olarak tanımlanmaktadır. Külttürleşme stresiyse, kaynağını kültürleşme sürecinden alan; psikolojik sağlığın olumsuz etkilenmesi, kaygı, depresyon, yabancılık, ötekilik duygusu, kimlik karmaşası ve psikosomatik semptomlar gibi davranışsal belirtilerle kendini gösterebilen bir tür stres biçimi olarak tanımlanmaktadır. Kültürleşme stresi fiziksel, psikolojik ve sosyal yönleri olan bir sağlık sorunu olarak tarif edilir (Berry vd., 1987, s. 492-493). Çalışmamızda, Suriyeli mültecilerin psikolojik ve fiziksel sağlığını etkileyebileceğini düşündüğümüz ve kültürleşme stresi kapsamında ele alabileceğimiz unsurların yanı sıra geçmiş yaşantıları ve gelecek beklentileri de ele alınmıştır. $\mathrm{Bu}$ amaçla, göç sürecindeki maddi ve manevi kayıpları, mevcut yaşam koşullarında problem olarak gördükleri konular, endişe duydukları meseleler, göç sonrasındaki duygu durumları ve geleceğe ilişkin beklentilerini saptayabilmek amacıyla katılımcıların görüşlerine başvurulmuştur. Türkiye'de göçmenlere yönelik problem olarak gördükleri konuların en fazla dil, hayat pahalılığı ve ayrımcılıkla ilişkili meseleler olduğu anlaşılmaktadır. Bunun yanı sıra barınma ve iş bulma gibi temel konularda sorunlar yaşadıkları görülmektedir. Dil sorununa dönük "[Türkçe bilmeden gündelik işleri yürütmek] Aslında çok zor. Mesela hastayım ama hastaneye gitmiyorum. Tercüman yok. Birbirimizi anlamıyoruz. Engel oluşturuyor" (Görüşmeci 10, 26.11.2018) ifadeleri ile kamusal hizmetlerin sadece varlığının değil aynı zamanda erişilebilirliğinin de önemli bir sorun olduğunun altı çizilmiştir. Beklentiler arasında gelir elde etmeye ve geçimlik sorununa dönük beklentiler temel yaşam beklentisi olarak öne çıkmıştır. Suriye'deki iç savaş sürecinde tüm sosyal haklarını kaybederek ülkesini terk etmek zorunda kalmış olan ve emeklilik hakkını kaybetmiş olan bir görüşmeci düşüncelerini "istihdam yaratmıyorlar, belediyeler her 10 çalışandan birini Suriyeli yapabilir. Avrupa'da sistem farklı orada dil eğitimi vs. veriyorlar. Dil sorun, Çalışma izni sorun. Gençlere sorun ben bu yaştan sonra balık tutmaktan başka bir şey istemiyorum" şeklinde ifade etmektedir (Görüşmeci 11, 17.12.2018). 
Grafik 17 Kent Mültecilerinin Türkiye’de Göçmen Olarak En Temel Gördükleri Sorunları

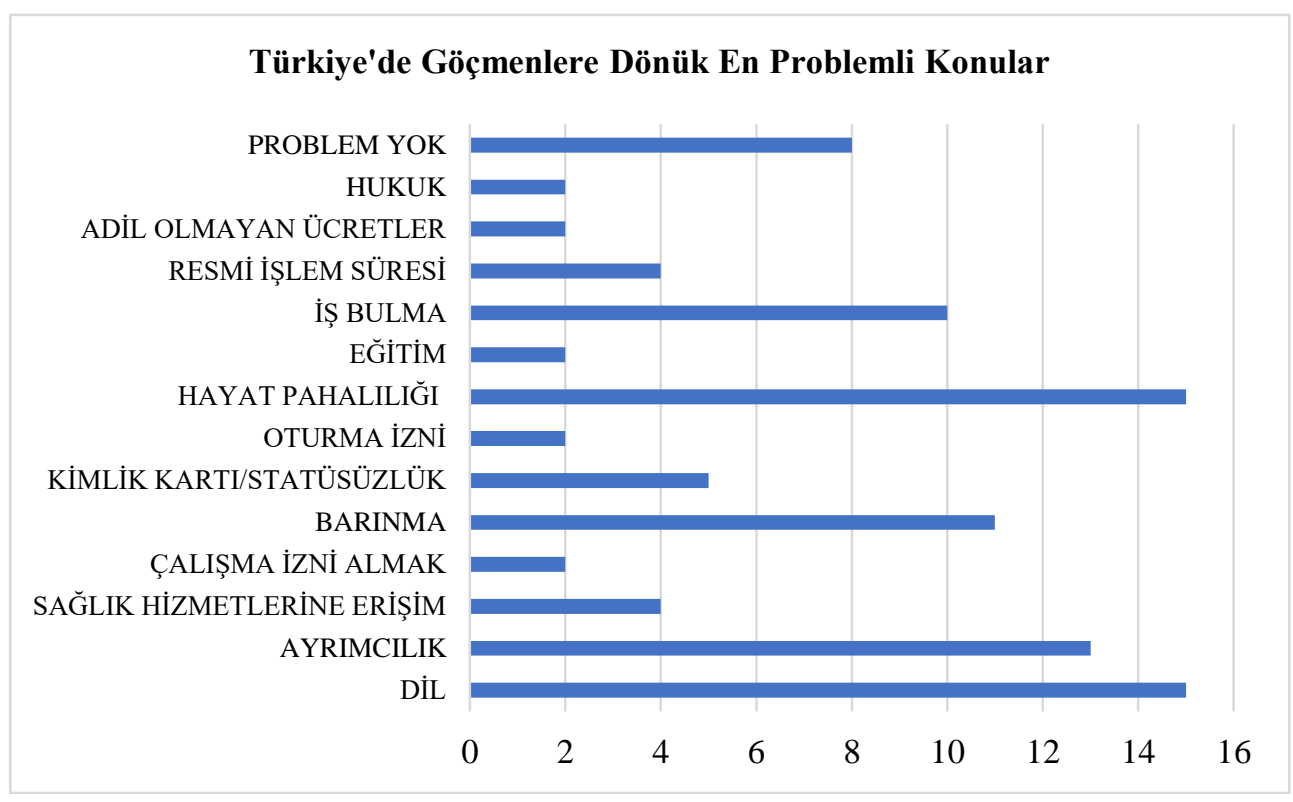

Suriyeli mültecilerin gelecekte de Türkiye'nin kalıcı bir üyesi olma isteğine ilişkin bilgi elde etmek amacıyla mevcut yasal statüleriyle ilgili herhangi bir kaygıları bulunup bulunmadığı ve mevcut statüyü değiştirme yönündeki fikirleri sorulmuştur. Katılımcıların 27'si Türkiye Cumhuriyeti vatandaşlığı istediğini ya da beklediğini ifade etmiştir. Ayrıca, geri gönderilme kaygısı ve statü/kimlik ile ilgili kaygılar da verilen cevaplar arasındadır. Vatandaşlık istemeyen görüşmecilerin memleketlerine geri dönme ya da başka bir ülkeye geçiş yapma hedefleri olduğu görülmüştür.

Grafik 18 Türkiye’deki Mevcut Statüye Yönelik Kaygı ve Beklentiler

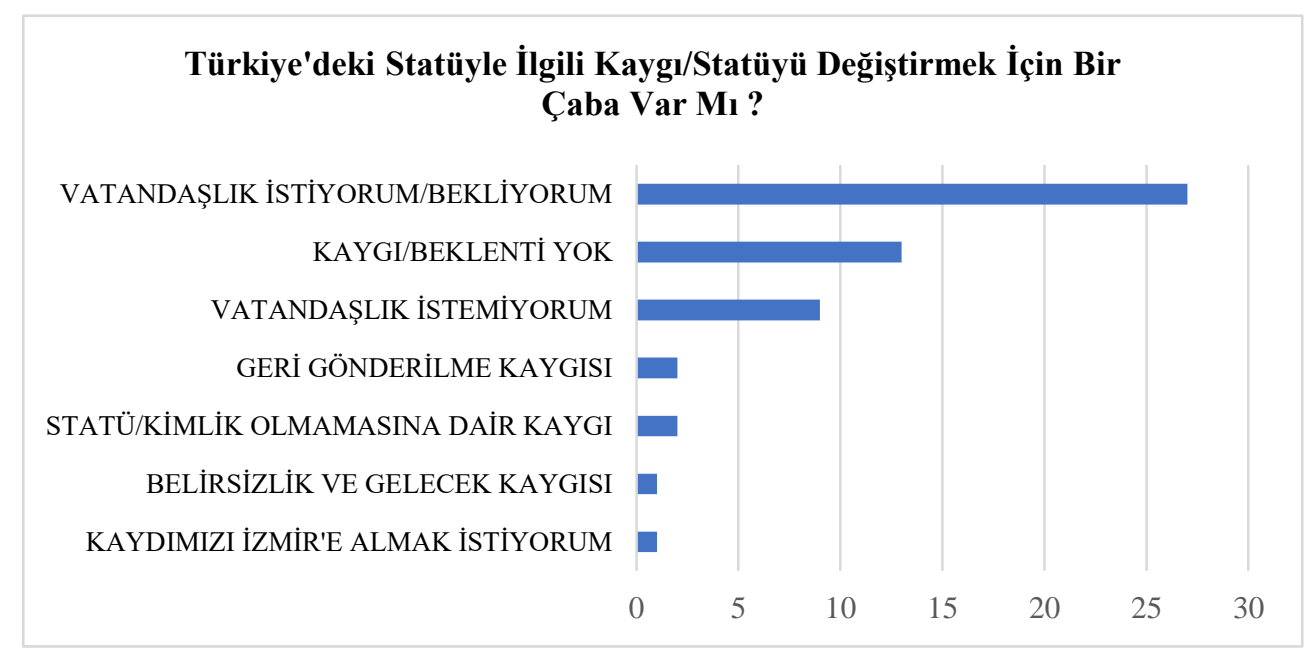

Katılımcıların kendilerini Türkiye'de ne kadar güvende hissettiği sorulduğunda, büyük çoğunluğun güvenlik sorunu görmediği anlaşılmaktadır. Bu durumu Suriye iç savaşının yarattığı ortama atıfla ifade ederek güvenlik sorununu 
savaş ve barışla ilişkili biçimde algıladıkları görülmüștür. Türkiye'de kendini güvende hissetmeyen katılımcılarınsa en çok sınır dışı edilme, geri gönderilme konularında kaygı duyduğu görülmektedir. Örneğin, bir görüşmeci bu durumu "6 ay sonra sizi gönderecekler, 2 ay sonra şu olacak, sizi kamplara toplayacaklar gibi şeyler duyuyoruz. Araftayız. Bugün buradayız ama yarın neredeyiz?” (Görüşmeci 6, 10.11.2018) ifadeleriyle aktarmaktadır.

Grafik 19 Türkiye'de Yaşamakla İlgili Hissedilen Kaygılar

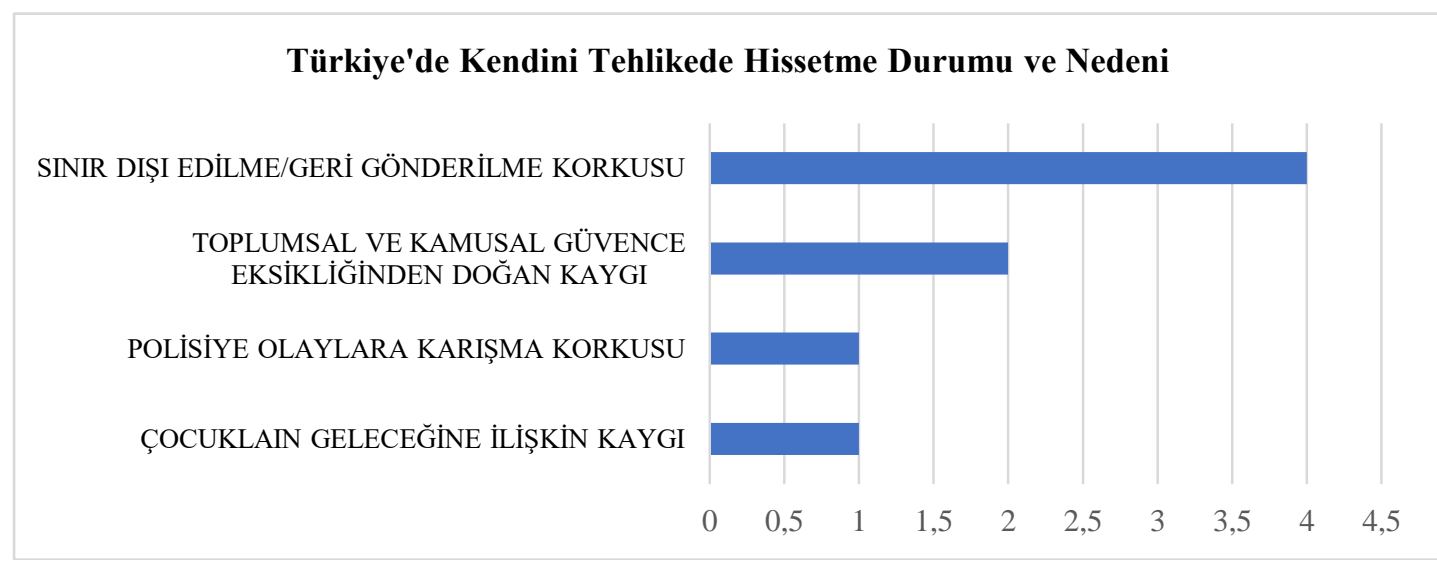

Katılımcıların Türkiye'de bulundukları süre zarfinda yalnızlık, korku, kaygı, umut ve yabancılık duygularının nasıl değiştiğini değerlendirmeleri istenmiştir. Savaştan sonra güvenli bir ortama erişen mültecilerin korku ve kaygı duygularının azaldığı, umut duygusunun arttığı; ancak diğer taraftan yabancılık ve yalnızlık duygularında Türkiye'ye geldikten sonra artı̧̧ yaşandığı ifade edilmiştir.

Grafik 20 Türkiye'de Yaşama Başladıktan Sonra Duyguların Değişimi

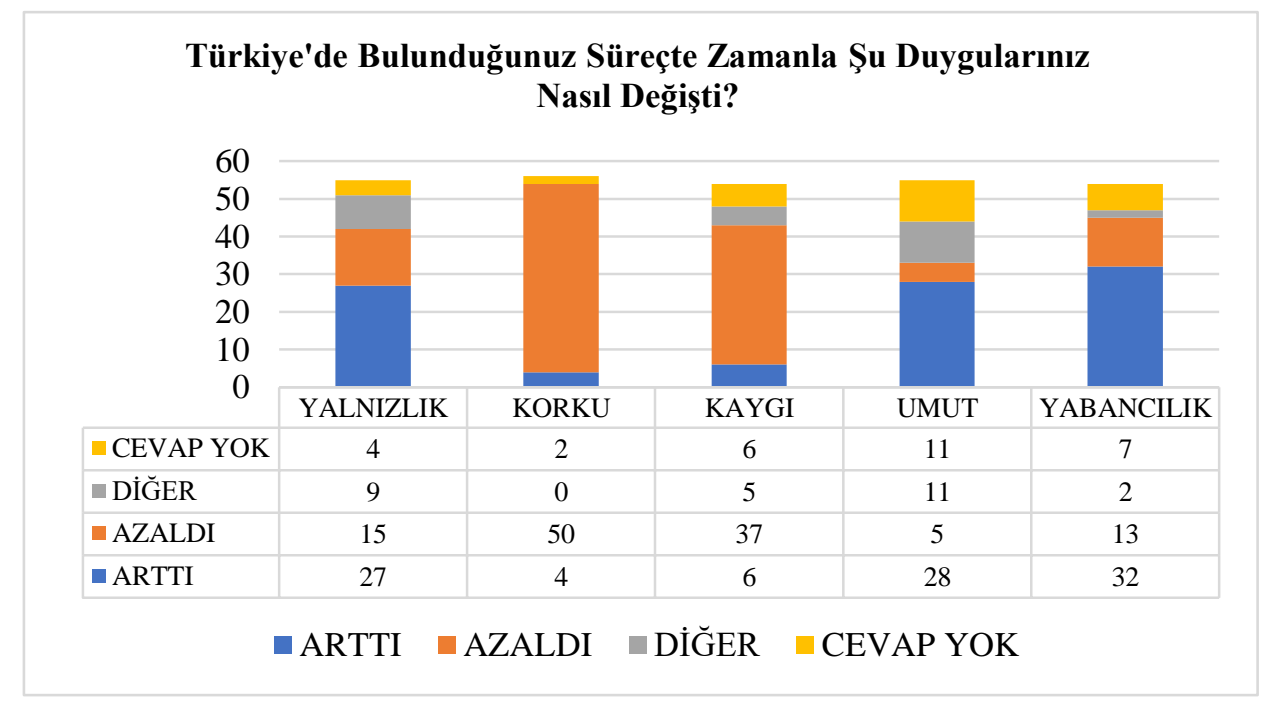

Son olarak göç sürecinin beklendiği üzere pek çok maddi ve manevi kayıp yarattı̆̆ görülmektedir. Katılımcılara savaştan itibaren yaşamış oldukları kayıpların neler olduğu sorulduğunda maddi kayıpların ve ölüm gibi travmatik 
yaşantıların ön plana çıkarıldığı görülmektedir. Bunun yanı sıra sosyal hayatta yaşanan değişimler, memleketten ve yakınlarından ayrılmış olmak da göç sürecinin yaratmış olduğu kayıplar arasında sıralanmıştır.

\section{SONUÇ VE TARTIŞMA:}

Bu çalışmada Suriyeli kent mültecilerin göç süreçleri ve yaşam koşulları, ekonomik, hukuksal, sosyal ve psikolojik boyutlarıyla ele alınmıştır. Çalışmaya konu olan ve TÜBİTAK tarafından finanse edilen araştırma projesinde, İzmir kentinin bir vaka çalışması olarak seçilmesinin temel nedenlerinden biri 2012 yılından sonra Suriye'den gelen kitlesel göçün varış noktalarından biri olan kentin bir "geçiş mekânı" olarak görülmesidir. İzmir, geçiş kenti fonksiyonuyla, Avrupa'ya ulaşmak isteyen göçmenlerin önemli duraklarından biri olmakla birlikte, yerleşmek ve kalıcı düzen kurmak amacıyla da tercih edilen bir hedef kenttir. Bu tercihlerin genel anlamda akrabalık bağları, kentin ucuz barınma imkânı sağlaması ve ekonomik faaliyetler tarafından şekillendiği görülmektedir. Suriyeli mültecilerin göç hikâyeleri incelendiğinde Türkiye sınırları dâhilinde ve dışında pek çok duraktan geçilerek İzmir'e ulaşıldığı görülmektedir. Bir diğer taraftan geleceğe dönük beklentiler göz önünde tutulduğunda sürecin dinamizmini koruduğu anlaşılmaktadır. Suriyeli mülteciler açısından uzun ya da kısa süreli ihtiyaçlara cevap veren pek çok duraktan geçilmiş olması ve ileriye dönük planlar, aktif bir göç sürecinden bahsetmeyi mümkün kılmaktadır. Suriye'deki savaşın ne zaman ve hangi koşullarda sona ereceği, savaş sona erse bile Türkiye'ye yerleşmiş sayıları milyonlara ulaşan mültecilerin ne kadarının geri döneceği belirsizliğini korumaktadır. Bu nedenle Suriyelilerin, Türkiye toplumunun kalıcı bir unsuru haline geldiğini ifade etmek yanlış olmayacaktır.

Ekonomik faaliyetleri ve çalışmakta oldukları işlerin nitelikleri göz önünde tutulduğunda Suriyelilerin işgücü piyasasındaki dezavantajlı konumunda, kayıt dışı istihdamın olumsuz etkileri ön plana çıkmaktadır. Öyle ki, yasal statü meselesinin Suriyeli mültecileri emek piyasasının en kırılgan işçileri durumuna getirdiği yorumuna varılabilmektedir. Bir diğer taraftan hem ekonomik şartların hem de sosyal ilişkilerin çıktıları, barınma koşullarında karşılaşllan güçlüklerle kendini göstermektedir. Öyle ki, düşük standartlardaki evlerde ikamet ediyor olmak ekonomik gelir düzeyinin bir sonucu; kiralık konut arayışında yaşanan zorluklarsa Türkiye vatandaşlarıyla kurulan sosyal ilişkilerin doğurgusu olarak karşımızda durmaktadır. Bunların yanı sıra evin geçimini üstlenmek üzere çalışmak durumunda olan ve bu sebeple eğitimine devam edemeyen okul çağındaki çocukların azımsanamayacak oranı, ekonomik koşulların çalışmamız kapsamında ele aldığımız neredeyse her başlıkta merkezi bir önem arz ettiğini göstermektedir.

Suriyeli kent mültecilerin yaşam koşullarını ve göç süreçlerini analiz ettiğimiz bu çalışmada iş gücü piyasasında yaşanan zorluklara, kentsel ve kamusal hizmetlere erişim koşullarına, sosyal uyum ve toplumsal kabul süreçlerini sekteye uğratan ayrımcılık, dışlanma gibi sorunlara değinilmiştir. Bütün bu bilgilerden hareketle Türkiye toplumuna yeni bir sosyal grup olarak eklenen Suriyeli mültecilerle kurulacak birlikte yaşam pratiğine katkı sağlayabilecek bütüncül, kalıcı ve kapsayıcı programlara ihtiyaç duyulduğu sonucuna varılabilmektedir.

$\mathrm{Bu}$ makale kapsamında yaşam koşulları başlı̆̆ı ile ilişkili olarak ele alınmamış olan konulardan bir tanesi yerel yönetimlerin kent mültecilerine sundukları hizmetlerdir. Belediyeler, 5393 sayılı Belediye Kanunun Hemşehri Hukuku başlıklı 13. Maddede ve çeşitli düzenlemelerden hareketle mültecilere hizmet sunumu açısından görevlendirilmiştir. Bu makalenin dayandığ 1 araştırma kapsamında 2017, 2018 ve 2019 yıllarında İzmir'de saha araştırmasının gerçekleştiği Basmane'de yetkili olan yerel yönetimlerle görüşmeler yapılmış, 2019 ve 2020 yıllarında araştırma ekibi tarafından gerçekleştirilen çalıştaylara yerel yönetim yetkilileri katılım göstermiş ve odak grup çalışmalarında yer almışlardır.

$\mathrm{Bu}$ görüşmeler göstermiştir ki yerel yönetimlerin sundukları hizmetlerde gösterdikleri tavır ya belediye başkanının kişisel vizyonuna dayalıdır ya da çeşitli mertebelerdeki personelin kişisel tutum ve davranışlarına tabiidir. Bunun temel nedeni, yerel yönetimlerin Suriye'den gelen göç ile kentte hemşehri statüsünde barınmakta olan mülteci nüfusuna dönük kurumsal bir yaklaşım ve tavır sergilememesi ya da sergilemekten kaçınmasıdır. Örneğin, kimi yerel yönetim yetkilileri, bu araştırma kapsamında sunulan çalışma alanında "kentsel dönüşüm" uygulamaları yapılacağı için ilgili nüfusun bu mahalleleri terk edeceğini ve bu kapsamda bir sorun olmadığını aktarmıştır. Kentte yapılan planlarda mülteci nüfusu, nüfus projeksiyonu ve kentsel donatı hesaplamalarına dahil edilmemiş̧ir. Çamur'a göre 
(2017), bahsi geçen hizmetler atölyeler, kurslar, ayni yardımlar vb. kısmi ve geçici eylemlerdir. 2019 yılından bu yana İzmir'de Konak Belediyesi mülteci merkezi gibi etkileşim ve kültürleşmeye hizmet verme potansiyeli olan fiziki mekanlar gibi eylemler üretmişlerdir. Ayrıca, Birleşmiş Milletler Kalkınma Programı, Birleşmiş Milletler Mülteciler Yüksek Komiserliği gibi uluslararası kurum kuruluşların İzmir Ofisleri’nin girişimlerinin de katkısıyla ile İzmir Büyükşehir Belediyesi stratejik plan, bütçe planı gibi dokümanlarda sorunu ele almaya başlamıștır. Bu durum Betts, Memişoğlu ve Ali (2021) tarafından ortaya koyulmuş olan belediye başkanlarının tutumlarının merkezi hükümet politikalarından daha sınırlayıcı ya da daha proaktif olabileceği savını desteklemektedir.

$\mathrm{Bu}$ çalışmada kentsel mültecilerin yaşam koşulları İzmir-Kapılar bağlamında çok yönlü ve çok boyutlu olarak ele alınmıştır ve keşfedici bir yaklaşımla işlenmiştir. Suriyelilerin yaşam şartlarına işaret eden her bir unsur, başlı başına ayrı bir araştırmanın problemi olarak ele alınabilecek nitelikte ve kapsamdadır. Bu çalışmada sunmuş olduğumuz bulgularının, farklı disiplinlerce gerçekleştirilecek çalışmalara kaynaklık edebilecek veriler sunması beklenmektedir.

Çıkar Çatışması: Yazarlar herhangi bir çıkar çatışmasının olmadığını beyan eder.

Etik Kurul İzni: Bu çalışma için etik kurul iznine gerek vardır. Bu çalışmaya ilişkin etik kurul izin talebi "Yıldız Teknik Üniversitesi Akademik Etik Kurulu” tarafindan 24.05.2017 tarihinde, 55779672-604.01.02-E.1705240179 sayılı belge ile onaylanmıştır.

Finansal Destek: Bu çalışma, TÜBİTAK 1003 Öncelikli Alanlar ve AR-GE programı kapsamında desteklenmekte olan "Kentsel Mültecilerin Adaptasyon ve Uyum Süreçlerine Yeni bir Bakış Açısı: Kapsayıcı Kent İnşası Amaçlı Sosyal İnovasyon Deneyi" başlıklı 117K826 (ana proje), 117K805ve $117 \mathrm{~K} 829$ kodlu projeler kapsamında gerçekleştirilmiştir.

Teşekkür: "Kentsel Mültecilerin Adaptasyon ve Uyum Süreçlerine Yeni bir Bakış Açısı: Kapsayıcı Kent İnşası Amaçlı Sosyal İnovasyon Deneyi" başlıklı 117K826 (ana proje), 117K805ve 117K829 kodlu projeler kapsamında gerçekleştirilmiş olan bu çalışma için tüm proje ekibine teşekkürü borç biliriz. Özellikle projenin İzmir ekibine katkılarından ötürü teşekkür eder, bu çalışma kapsamında hazırlanmış olan tüm grafik, tablo ve görsel materyalin projenin İzmir ekibi tarafından hazırlanmış olduğunu beyan ederiz.

\section{KAYNAKÇA:}

\section{Kitaplar ve Kitap Bölümleri:}

Harvey, D. (2013). Asi şehirler, A. D. Temiz, (Çev.) İstanbul: Metis Yayınları.

Karakaya Ayalp, E. (2020). Kentsel Mültecilerin Adaptasyon ve Uyum Süreçlerine Yeni bir Bakış Açısı: Kapsayıcı Kent İnşası Amaçlı Sosyal İnovasyon Modeli. S. Fedakar, A. Karadağ ve A., S., Erkul Yağcı (der.), Tarih Boyunca Uluslararası Göç ve Göçmenlik içinde (ss. 319-331). Ege Üniversitesi Yayınları: İzmir.

\section{Makaleler:}

Akbaş, S., Ünlütürk Ulutaş, Ç. (2018). Küresel fabrika kentinin görünmeyen işçileri: Denizli işgücü piyasasında Suriyeli göçmenler. Çalışma ve Toplum, 56(1), 167- 192.

Berry, J. W. (2005). Acculturation: Living successfully in two cultures. International Journal of Intercultural Relations, 29(6), 697-712.

Berry, J. W., Sabatier, C. (2010). Acculturation, discrimination, and adaptation among second generation immigrant youth in Montreal and Paris. International Journal of Intercultural Relations, 34(3), 191-207. 
Berry, J. W., Kim, U., Minde, T., Mok, D. (1987). Comparative studies of acculturative stress. International Migration Review, 21(3), 491-511.

Betts, A., Memişoğlu, F., Ali, A. (2021). What Difference do Mayors Make? The Role of Municipal Authorities in Turkey and Lebanon's Response to Syrian Refugees. Journal of Refugee Studies, 34(1), 491-519,

Çalışkan, A. (2020). Geçici koruma kapsamındaki Suriyelilerin mekân tercihlerinde rasyonelliğin analizi. Dokuz Eylül Üniversitesi Sosyal Bilimler Enstitüsü Dergisi, 22(3), 1189-1204.

Çamur, A. (2017). Suriyeli mülteciler ve belediyelerin sorumluluğu İzmir örneği. Bitlis Eren Üniversitesi Sosyal Bilimler Dergisi, 6(2), 113-129.

Çelik, Ç., İçduygu, A. (2019). Schools and refugee children: thecase of Syrians in Turkey. International Migration, 57 (2), 253-267.

Çetin, İ. (2016). Suriyeli Mültecilerin İşgücüne Katılımları ve Entegrasyon: Adana-Mersin Örneği. Gaziantep University Journal of Social Sciences, 15(4) 1001-1016.

Kaygısız, İ. (2017). Suriyeli mültecilerin Türkiye işgücü piyasasına etkileri. Friedrich-Ebert-Stiftung. 1-20.

Keleşmehmet, H. (2018). Dünyada ve Türkiye'de göçmen sağlığı. The Journal of Turkish Family Physician, 9(4), 119-126.

Köser Akçapar, Ş. Şimsek, D. (2018). The politics of Syrian Refugees in Turkey: A question of inclusion and exclusion through citizenship. Social Inclusion, 6 (1), 176-187.

Lordoğlu, K., Aslan, M. (2016). En Fazla Suriyeli Göçmen Alan Beş Kentin Emek Piyasalarında Değişimi: 20112014. Çalışma ve Toplum, 49(2) 789-808.

Makovsky, A. (2019). Turkey's refugee dilemma. Tiptoeing toward integration. Foreign Policy and Security. Erişim: $\quad$ https://www.americanprogress.org/issues/security/reports/2019/03/13/467183/turkeys-refugee-dilemma/ (Erişim Tarihi: 03.09.2021).

Massey, D. S., Arango, J., Hugo, G., Kouaouci, A., Pellegrino, A., Taylor, J. E. (1993). Theories of international migration: A review and appraisal. Population and Development Review, 431-466.

Pettigrew, T. F. (1998). Inter group contact theory. Annual Review of Psychology, 49(1), 65-85.

Sam, D. L., Berry, J. W. (2010). Acculturation: When individuals and groups of different cultural backgrounds meet. Perspectives on Psychological Science, 5(4), 472-481.

Şahankaya Adar, A. (2018). Türkiye'de yeni prekarya Suriyeli işgücü mü?. Çalışma ve Toplum, 56(1) 13-36.

Syria- Local Government (2021). Britannica. Erişim: https://www.britannica.com/place/Syria/Local-government (Erişim Tarihi: 01.02.2021).

Safak-Ayvazoglu, A., ve Kunuroglu, F. (2021). Acculturation experiences and psychological well-being of Syrian refugees attending universities in Turkey: A qualitative study. Journal of Diversity in Higher Education, 14(1), 96-109. https://doi.org/10.1037/dhe0000148

Şafak-Ayvazoğlu, A., Kunuroğlu, F., Yağmur, K. (2021). Psychological and socio-cultural adaptation of Syrian refugees in Turkey. International Journal of Intercultural Relations, 80, 99-111.

Şimşek, D. (2019). Suriyeli mültecilerin Avrupa'ya yayılımı: analitik ve karşılaştırmalı bir değerlendirme. Adam Akademi Sosyal Bilimler Dergisi, 9(2), 493-518. 
Yavuz, Ö., Mızrak, S. (2016). Acil durumlarda okul çağındaki çocukların eğitimi: Türkiye'deki Suriyeli mülteciler örneği. Göç Dergisi, 3(2), 175-199.

Yıldız, A., Uzgören, E. (2016). Limits to temporary protection: non-camp Syrian refugees in İzmir, Turkey. Southeast European and Black Sea Studies, 16(2), 195-211.

\section{Tebliğler:}

Anbarc1, M., Giran, Ö., Türkan, Y. S., Manisal1, E. (2011). Ürün olarak konut kavramı ve Türkiye'deki konut satışlarının ürün hayat eğrisi yaklaşımıyla değerlendirilmesi. 6. İnşaat Yönetimi Kongresi, (25-27 Kasım 2011), Bildirileri içinde (ss. 291-303). Bursa: TMMOB İnşaat Mühendisleri Odas1.

Balkır, Z. G. (2010). Konut hakkı ve ihlalleri: kentli haklarının doğuşu, Sosyal Haklar Ulusal Sempozyumu (s. 342). Denizli: Pamukkale Üniversitesi.

\section{Raporlar:}

HABITAT III (2014). Üçüncü Birleşmiş Milletler Konut ve Sürdürü̈lebilir Yerleşmeler Konferansı Türkiye Ulusal Raporu https://habitat.csb.gov.tr/habitat-iii-turkiye-ulusal-raporu-i-5737 (Erişim Tarihi: 10.04.2021).

Huang, C., Graham, J. (2018) Are Refugees Located Near Urban Job Opportunities? Center for Global Development, Center for Global Development. https://www.cgdev.org/sites/default/files/are-refugees-located-nearurban-job opportunities.pdf (Erişim Tarihi: 22.02.2021).

IOM- International Organization for Migration (Birleşmiş Milletler Uluslararası Göç Örgütü). (2017). World Migration Report 2018. https://www.iom.int/wmr/world-migration-report-2018https://www.iom.int/wmr/worldmigration-report-2018(Erişim Tarihi: 21.02.2021).

Kalkınma Atölyesi (2016). Türkiye'de Mevsimlik Tarımsal Üretimde Yabancı Göçmen İşçiler Mevcut Durum Raporu. Yoksulluk nöbetinden yoksulların rekabetine. http://www.ka.org.tr (Erişim Tarihi: 10.04.2021)

Özbakır, A., Çakır, B., Karakaya Ayalp, E., Kurtarır, E., Biricik, G., Karan, O.,.., Ayalp, E. (2021). Kentsel Mültecilerin Adaptasyon ve Uyum Süreçlerine Yeni Bir Bakış Açısı: "Kapsayıcı Kent İnşaası" Amaçlı "Sosyal İnovasyon Deneyi", TÜBITTAK 1003 Öncelikli Alanlar ve AR-GE Projeleri, 117K826, 117K829, 117K805 Kodlu Projeler Sonuç Raporu, Ankara: TÜBİTAK.

Türmen, T. (2011) Eğitim Reformu Girişimi. Eğitim İzleme Raporu 2001. "Önsöz: Afet Zamanlarında Eğitim" (Erişim Tarihi: 10.04.2021).

UNESCO (2016). Cities Welcoming Refugees and Migrants. Erişim: https://unesdoc.unesco.org/ark:/48223/pf0000246558 (Erişim Tarihi: 12.01.2021).

UNHCR- United Nations High Commissionaire of Refugees (Birleşmiş Milletler Mülteciler Yüksek Komiserliği). (2017). Syria Regional Refugee Response. Operational Portal Refugee Situations. Erişim: https://data2.unhcr.org/en/situations/syria (Erişim Tarihi: 10.01.2021).

\section{Web Siteleri:}

İzmir Valiliği İl Göç İdaresi Resmî web sitesi. İstatistiklerle İzmir. Erişim: http://www.izmir.gov.tr/istatistiklerleizmir( Erişim Tarihi: 10.06.2018). 


\section{EK: GÖRÜŞMELER VE GÖRÜŞMECİLERİN PROFİLLERİ}

\begin{tabular}{|c|c|c|c|}
\hline $\begin{array}{l}\text { Görüşmeci } \\
\text { No }\end{array}$ & Görüşmeci Profili & $\begin{array}{l}\text { Görüşme } \\
\text { Tarihi }\end{array}$ & $\begin{array}{l}\text { Görüşmenin } \\
\text { Yapıldığı Mahalle }\end{array}$ \\
\hline Görüşmeci 1 & $\begin{array}{l}\text { Cinsiyet: Kadın } \\
\text { Yaş: } 27 \\
\text { Medeni Durum ve Aile: Evli, } 3 \text { Çocuk Sahibi } \\
\text { Eğitim Durumu: Eğitim Almamış } \\
\text { İstihdam: Parça Baş1 Nakış İşçiliği }\end{array}$ & 3.11 .2018 & Kadifekale \\
\hline Görüşmeci 2 & $\begin{array}{l}\text { Cinsiyet: Kadın } \\
\text { Yaş: } 31 \\
\text { Medeni Durum ve Aile: Tek ebeveyn, } \\
5 \text { Çocuk Sahibi } \\
\text { Eğitim Durumu: Ortaokul } \\
\text { İstihdam: Günlük düzensiz işler }\end{array}$ & 3.11 .2018 & Kadifekale \\
\hline Görüşmeci 3 & $\begin{array}{l}\text { Cinsiyet: Kadın } \\
\text { Yaş: } 24 \\
\text { Medeni Durum ve Aile: Evli, } 3 \text { Çocuk Sahibi } \\
\text { Eğitim Durumu: Ortaokul } \\
\text { İstihdam: Parça başı nakış işleri }\end{array}$ & 3.11 .2018 & Kadifekale \\
\hline Görüşmeci 4 & $\begin{array}{l}\text { Cinsiyet: Erkek } \\
\text { Yaş: } 34 \\
\text { Medeni Durum ve Aile: Evli, } 3 \text { Çocuk Sahibi } \\
\text { Eğitim Durumu: Ortaokul } \\
\text { İstihdam: İnşaat işçisi }\end{array}$ & 28.10 .2018 & Sakarya \\
\hline Görüşmeci 5 & $\begin{array}{l}\text { Cinsiyet: Kadın } \\
\text { Yaş: } 32 \\
\text { Medeni Durum ve Aile: Evli, } 1 \text { Çocuk Sahibi } \\
\text { Eğitim Durumu: Üniversite } \\
\text { İstihdam: Arapça özel ders öğretmenliği }\end{array}$ & 20.11 .2018 & Kubilay \\
\hline Görüşmeci 6 & $\begin{array}{l}\text { Cinsiyet: Kadın } \\
\text { Yaş: } 27 \\
\text { Medeni Durum ve Aile: Evli, } 6 \text { Çocuk Sahibi } \\
\text { Eğitim Durumu: İlkokul } \\
\text { İstihdam: Çalışmıyor }\end{array}$ & 10.11 .2018 & Kadifekale \\
\hline Görüşmeci 7 & $\begin{array}{l}\text { Cinsiyet: Kadın } \\
\text { Yaş: } 30 \\
\text { Medeni Durum ve Aile: Evli, } 4 \text { Çocuk Sahibi } \\
\text { Eğitim Durumu: İlkokul } \\
\text { İstihdam: Çalışmıyor }\end{array}$ & 2.11 .2018 & Pazaryeri \\
\hline Görüşmeci 8 & $\begin{array}{l}\text { Cinsiyet: Erkek } \\
\text { Yaş: } 68\end{array}$ & 22.12 .2018 & Süvari \\
\hline
\end{tabular}

${ }^{8}$ Bu bölümde sadece makale metninde doğrudan alıntı yapılan görüşmelerle ve görüşmecilerle ilgili bilgilere yer verilmiştir. Metinde de aktarıldığı üzere bu çalışmadaki analizlere kaynaklık eden derinlemesine görüşmelerin toplam sayısı 60’tır.

İzmir'in Kapıları: Kent Mültecilerinin Göç Hikayeleri ve Yaşam Koşulları

Journal of Urban Academy | Volume: 14 Issue: 3 | ISSN: 2146-9229

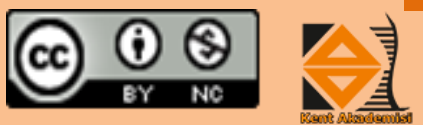




\begin{tabular}{|c|c|c|c|}
\hline & $\begin{array}{l}\text { Medeni Durum ve Aile: Evli, } 5 \text { Çocuk Sahibi } \\
\text { Eğitim Durumu: Üniversite } \\
\text { İstihdam: Çalışmıyor }\end{array}$ & & \\
\hline Görüşmeci 9 & $\begin{array}{l}\text { Cinsiyet: Kadın } \\
\text { Yaş: } 24 \\
\text { Medeni Durum ve Aile: Evli, } 3 \text { Çocuk Sahibi } \\
\text { Eğitim Durumu: Ortaokul } \\
\text { İstihdam: Çalışmıyor }\end{array}$ & 22.12 .2018 & Süvari \\
\hline Görüşmeci 10 & $\begin{array}{l}\text { Cinsiyet: Kadın } \\
\text { Yaş: } 24 \\
\text { Medeni Durum ve Aile: Evli, } 2 \text { Çocuk Sahibi } \\
\text { Eğitim Durumu: Lise } \\
\text { İstihdam: Çalışmıyor }\end{array}$ & 26.11 .2018 & Kadifekale \\
\hline Görüşmeci 11 & $\begin{array}{l}\text { Cinsiyet: Erkek } \\
\text { Yaş: } 60 \\
\text { Medeni Durum ve Aile: Evli, } 9 \text { Çocuk Sahibi } \\
\text { Eğitim Durumu: İlkokul } \\
\text { İstihdam: İnşaat İşçisi }\end{array}$ & 17.12 .2018 & Ali Reis \\
\hline
\end{tabular}

